\section{Pacific Northwest}

National Laboratory

Operated by Battelle for the

U.S. Department of Energy

\title{
Simulating the Flow Field Upstream of the Dworshak Dam Regulating Outlets
}

\author{
C.B. Cook \\ M.C. Richmond
}

March 2004

Prepared for Idaho Fish and Game, Ahsahka, Idaho Dworshak Dam Assessment and Fisheries Investigations Bonneville Power Administration Project 1987-099-00

Prepared for the U.S. Department of Energy under Contract DE-AC06-76RL01830 


\title{
DISCLAIMER
}

This report was prepared as an account of work sponsored by an agency of the United States Government. Neither the United States Government nor any agency thereof, nor Battelle Memorial Institute, nor any of their employees, makes any warranty, express or implied, or assumes any legal liability or responsibility for the accuracy, completeness, or usefulness of any information, apparatus, product, or process disclosed, or represents that its use would not infringe privately owned rights. Reference herein to any specific commercial product, process, or service by trade name, trademark, manufacturer, or otherwise does not necessarily constitute or imply its endorsement, recommendation, or favoring by the United States Government or any agency thereof, or Battelle Memorial Institute. The views and opinions of authors expressed herein do not necessarily state or reflect those of the United States Government or any agency thereof.

\author{
PACIFIC NORTHWEST NATIONAL LABORATORY \\ operated by \\ BATTELLE \\ for the \\ UNITED STATES DEPARTMENT OF ENERGY \\ under Contract DE-AC06-76RL01830
}

Printed in the United States of America
Available to DOE and DOE contractors from the Office of Scientific and Technical Information,
P.O. Box 62, Oak Ridge, TN 37831-0062;
ph: (865) 576-8401
fax: (865) 576-5728
email: reports@adonis.osti.gov

\author{
Available to the public from the National Technical Information Service, \\ U.S. Department of Commerce, 5285 Port Royal Rd., Springfield, VA 22161 \\ ph: (800) 553-6847 \\ fax: (703) $605-6900$ \\ email: orders@ntis.fedworld.gov \\ online ordering: http://www.ntis.gov/ordering.htm
}






\title{
Simulating the Flow Field Upstream of the Dworshak Dam Regulating Outlets
}

\author{
C.B. Cook \\ M.C. Richmond
}

March 2004

Prepared for Idaho Fish and Game, Ahsahka, Idaho Dworshak Dam Assessment and Fisheries Investigations

Bonneville Power Administration Project 1987-099-00

Pacific Northwest National Laboratory

Richland, Washington 99352 


\section{Summary}

The Pacific Northwest National Laboratory numerically modeled flow conditions upstream of the regulating outlets at Dworshak Dam, North Fork Clearwater River, Idaho. The Pacific Northwest National Laboratory conducted this work for the Idaho Department of Fish and Game under contract number 43857A in support of Idaho Department of Fish and Game Project 1987-099-00 with the Bonneville Power Administration.

Numerical simulations were performed using the computational fluid dynamics model Flow-3D, a peer reviewed and validated three-dimensional Reynolds-averaged Navier-Stokes hydrodynamic model. Results were studied to determine the impacts of water surface elevation and discharge though the three regulating outlets on flow velocities in the reservoir forebay. These simulations were in general support of a larger research program conducted by the Idaho Department of Fish and Game that is evaluating the efficacy of strobe lights to deter fish from entering the regulating outlets and powerhouse turbine intakes.

Simulation results indicate that large variations in forebay water velocities occur over the typical range of regulating outlet operations and seasonal water surface fluctuations. As expected, water velocities generally increase with larger outlet gate openings and higher water surface elevations. Simulations span typical regulating outlet operations: forebay water surface elevations between $1460 \mathrm{ft}$ and $1600 \mathrm{ft}$ and regulating outlet gate valve openings between $1 \mathrm{ft}$ and $10 \mathrm{ft}$ open. In addition, simulations examined flow conditions when only one or two of the three regulating outlets were operating. The resulting matrix of 24 unique simulations have been distilled and summarized in this report. 


\section{Acknowledgements}

We sincerely appreciate the cooperation, assistance, and dedication of the following persons:

- Idaho Fish and Game

o Eric Stark (project leader)

o Melo Maiolie (program leader)

- US Army Corps of Engineers, Walla Walla District

o Rick Emmert (structural drawings)

- Pacific Northwest National Laboratory

o John Serkowski (graphics support)

o Julie Hughes (contract support) 


\section{Contents}

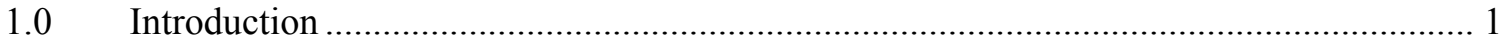

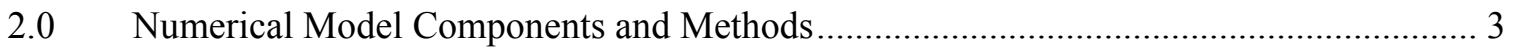

2.1 Dworshak Dam Structural Components .............................................................. 3

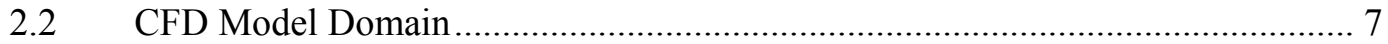

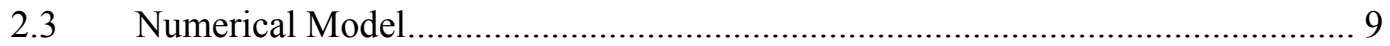

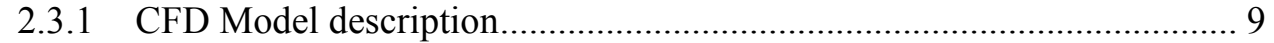

2.3.2 Boundary Conditions and Assumptions .............................................. 9

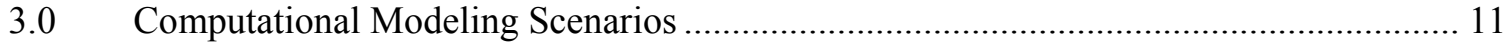

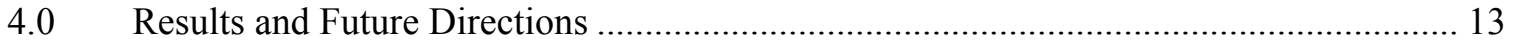

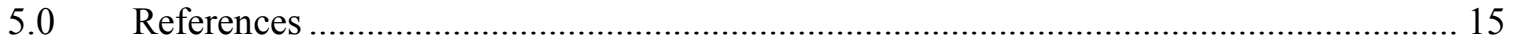

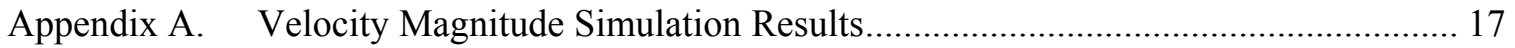




\section{Figures}

Figure 1 Location of Dworshak Dam in relation to other dams in the Snake and Columbia

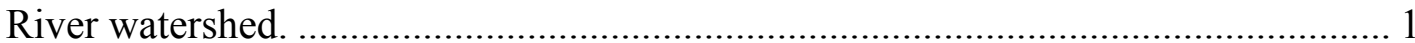

Figure 2 Schematic depicting the upstream face of Dworshak Dam................................ 3

Figure 3 Plan View Drawing of Regulating Outlet 3 .................................................... 5

Figure 4 Vertical Side View Drawing of a Regulating Outlet............................................ 6

Figure 5 CFD mesh domain extent ................................................................... 7

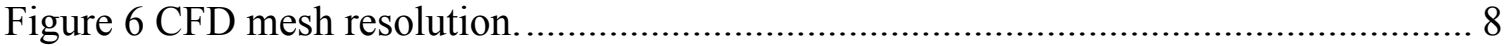

Figure 7 Simulation results for Run 1................................................................. 12

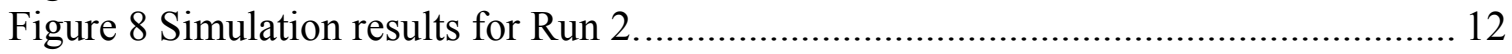

\section{Tables}

Table 1 Matrix of simulations performed during the project.......................................... 11 


\subsection{Introduction}

Dworshak Dam is a large hydroelectric dam located on the North Fork of the Clearwater River in Western Idaho (Figure 1). Downstream of the dam, the Clearwater River enters the Snake River near Clarkston,WA and Lewiston, ID. During late spring and summer water is released from lower levels of the reservoir to help cool water temperatures in the Lower Snake River downstream of the Clearwater and Snake River confluence. These cooler waters improve thermal conditions for endangered salmon in the Lower Snake River, and often push water temperatures below the state/federally mandated temperature criterion.

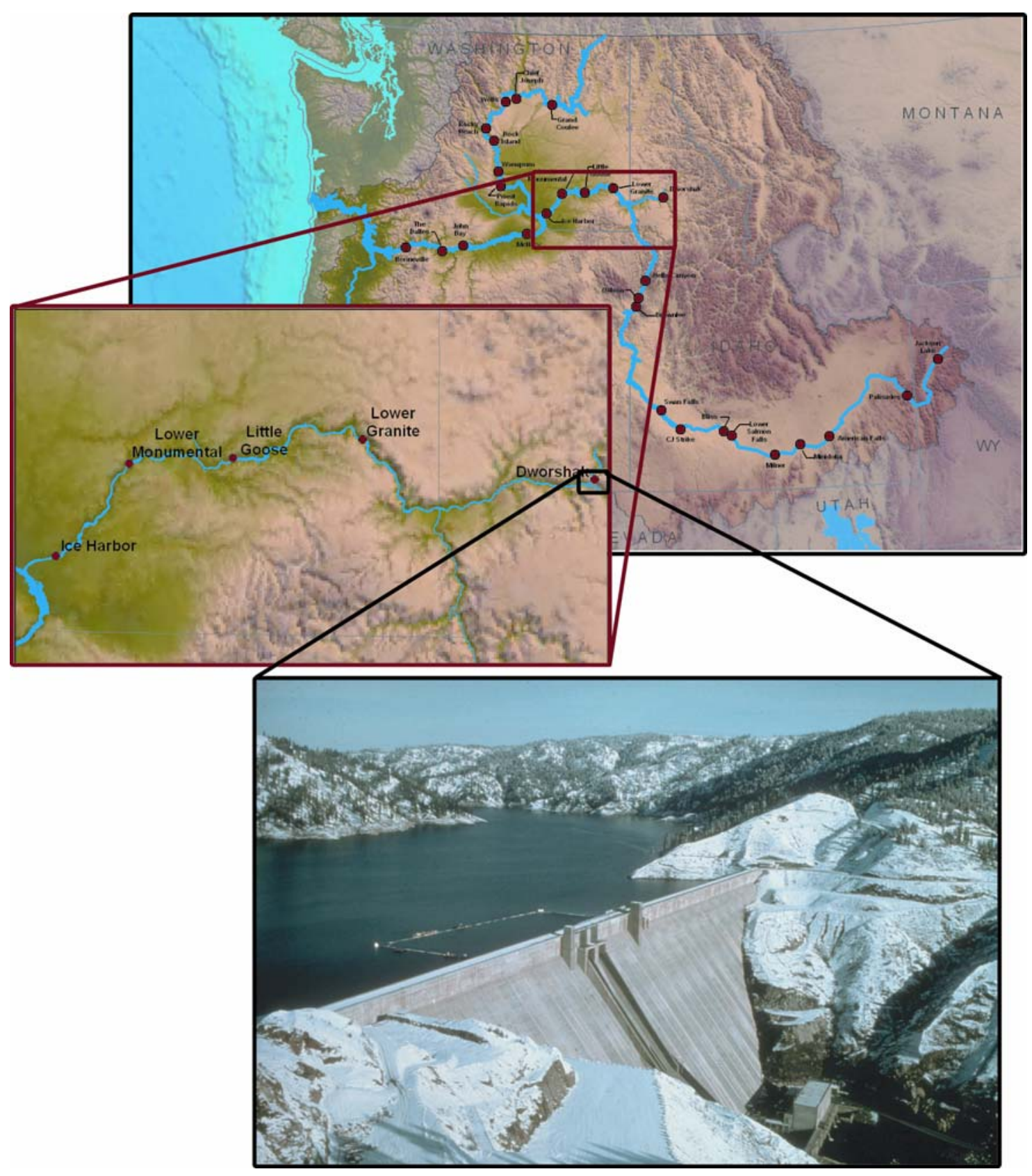

Figure 1 Location of Dworshak Dam in relation to other dams in the Snake and Columbia Rivers watershed. 
Three regulating outlet intakes (ROs) were placed in the dam during original construction. The upstream intake openings are $22 \mathrm{ft}$ tall by $16 \mathrm{ft}$ wide at the face of the dam. These bell mouth intakes taper once inside the dam to approximately $12.5 \mathrm{ft}$ tall by $9 \mathrm{ft}$ wide at the tainter gate valve (approximately $30 \mathrm{ft}$ inside the dam). Depending upon forebay elevation and tainter gate opening, discharges through each RO can exceed 10,000 cfs.

Operation of the ROs depends upon downstream water needs and the quantity of flow entering Dworshak Reservoir. Since hydroelectric power is not generated when flow passes through the ROs, they are not the preferred method for passing water through the dam. The ROs are necessary however during certain periods of the year when the forebay water surface is below the spillway crest and outflows required from the dam surpass powerhouse capacity. When the ROs are operated, fish passing through the ROs may be injured or killed. The Idaho Department of Fish and Game is currently investigating the use of strobe lights, placed upstream of the RO entrances, as a method to deter fish from entering the RO intakes.

Optimal placement of the strobe light apparatus requires understanding of the flow field upstream of the RO intakes. To obtain this information, and to answer general questions regarding the scale of velocity gradients near the RO entrances, a computational fluid dynamic (CFD) model was constructed. Although originally it was proposed that field data be obtained to validate this model, the scope of work was later changed. This scope change occurred primarily because the ROs were not operated during 2003. As a result of this change, additional CFD simulations were performed to satisfy the contract. These additional simulations span a wider range of water surface elevations than what was originally proposed. 


\subsection{Numerical Model Components and Methods}

\subsection{Dworshak Dam Structural Components}

The three regulating outlets (ROs) at Dworshak Dam are relatively deep and small structures on the face of the dam. Figure 2 displays their location with respect to other structures along the upstream face. In this figure, the water surface has been placed at elevation $1600 \mathrm{ft}$, although the normal operational range is between elevations 1445 and $1600 \mathrm{ft}$ (USACE, 1986). The ROs are numbered sequentially from one to three, beginning with the left (looking downstream left/right sign convention) outlet, following the engineering drawings supplied from the Walla Walla District, US Army Corps of Engineers.

The upper elevation of the bell mouth intake is at elevation $1373 \mathrm{ft}$ MSL (mean sea level). To the right of RO3, the main structural components of the powerhouse penstock intakes were constructed in the numerical model. Because the ROs are several hundred feet to the side of the powerhouse intakes, the details of the selective withdrawal structures in front of the intakes were not constructed in the CFD model, and hence are not displayed in the figure. The three operating powerhouse intakes are visible in Figure 2, beginning approximately $230 \mathrm{ft}$ to the right of RO3.



Figure 2 Schematic depicting the upstream face of Dworshak Dam 
Specific details regarding the ROs are excerpted from USACE (1986):

Three outlets are available for evacuation of reservoir storage below the spillway crest (elevation 1,545). The center outlet is located beneath the intermediate pier which separates the two spillway bays. The other two outlets are also located beneath the spillway, but these outlets flank the spillway gates. Discharge capacity of the three outlets varies from 23,100 cfs at minimum pool elevation 1,445 feet to 39,750 cfs at full pool elevation 1,600 feet. The outlets all seal at elevation 1,350 by hydraulically operated tainter valves. The tainter valves are 9 feet wide by 12.5 feet high.

Discharge through these outlets is controlled through the use of three tainter gate valves located approximately $30 \mathrm{ft}$ inside the dam. Operation of these outlets is described in USACE (1986):

The tainter valves are an eccentric-trunnion type and are 9 feet wide by 12.5 feet high. The principal elements of a valve are the skin-plate assembly, vertical girders, struts, and trunnions. Modified low-alloy steel is used for the skin plate, and the balance of the gate is fabricated from steel. The valve struts are bolted to the trunnion arms with high-strength bolts for future removal of the valve, if necessary.

Valve operation consists of three phases: retraction, raising or lowering, and sealing. Rotation of the eccentric-trunnion shafts by a pivoted hydraulic cylinder and lever arm arrangement either advances or retracts the valve 3/4 inch. Each valve is raised or lowered by another pivot-mouthed hydraulic cylinder. Individual hydraulic systems are provided for each tainter valve and serve both the operating cylinder and the cylinder which operates the eccentric.

Approximate valve operating times, including retraction and sealing operations, are 2-1/4 minutes for raising completely and 3 minutes for lowering from the full raised position. A complete set of operating controls, position sensing devices, and indicators are provided for each valve machinery room. Remote controls and indicators are provided in the powerhouse. A 100-kW emergency generator is located in the electrical room (elevation 1,580) in monolith 25 for supplying power for operation of spillway and outlet gates during an interruption in the regular power supply.

The engineering drawings shown in Figures 3 and 4 were obtained from Walla Walla District, US Army Corps of Engineers. These drawings display the specific engineering details of the ROs. Figure 3 is a plan view image specifically for RO3. ROs 2 and 1 are similar in construction, although the centerline dimension changes from $5072 \mathrm{ft}$ to $5000 \mathrm{ft}$ and $4927 \mathrm{ft}$, respectively. Figure 4 is a side view through a generic RO and details are approximately the same for all three ROs. 


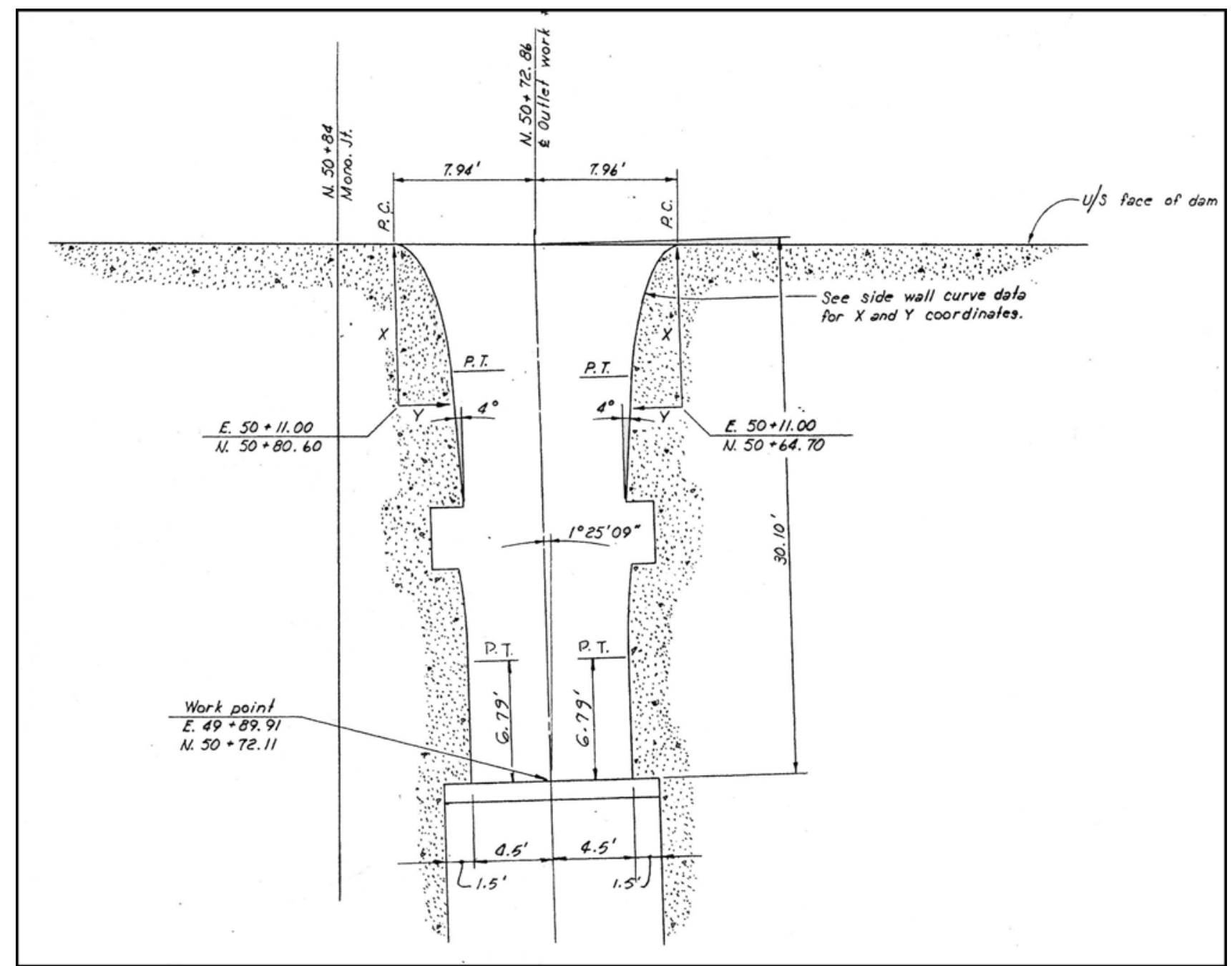

Figure 3 Plan View Drawing of Regulating Outlet 3. Drawing scanned from USACE engineering drawing sheet 157, file no DWD-1-4-17/26. Sheet label "Dworshak Dam and Reservoir, Outlet Works, Bellmouth Intake, Horizontal and Vertical Control". Sheet drawn on May 2, 1967. 


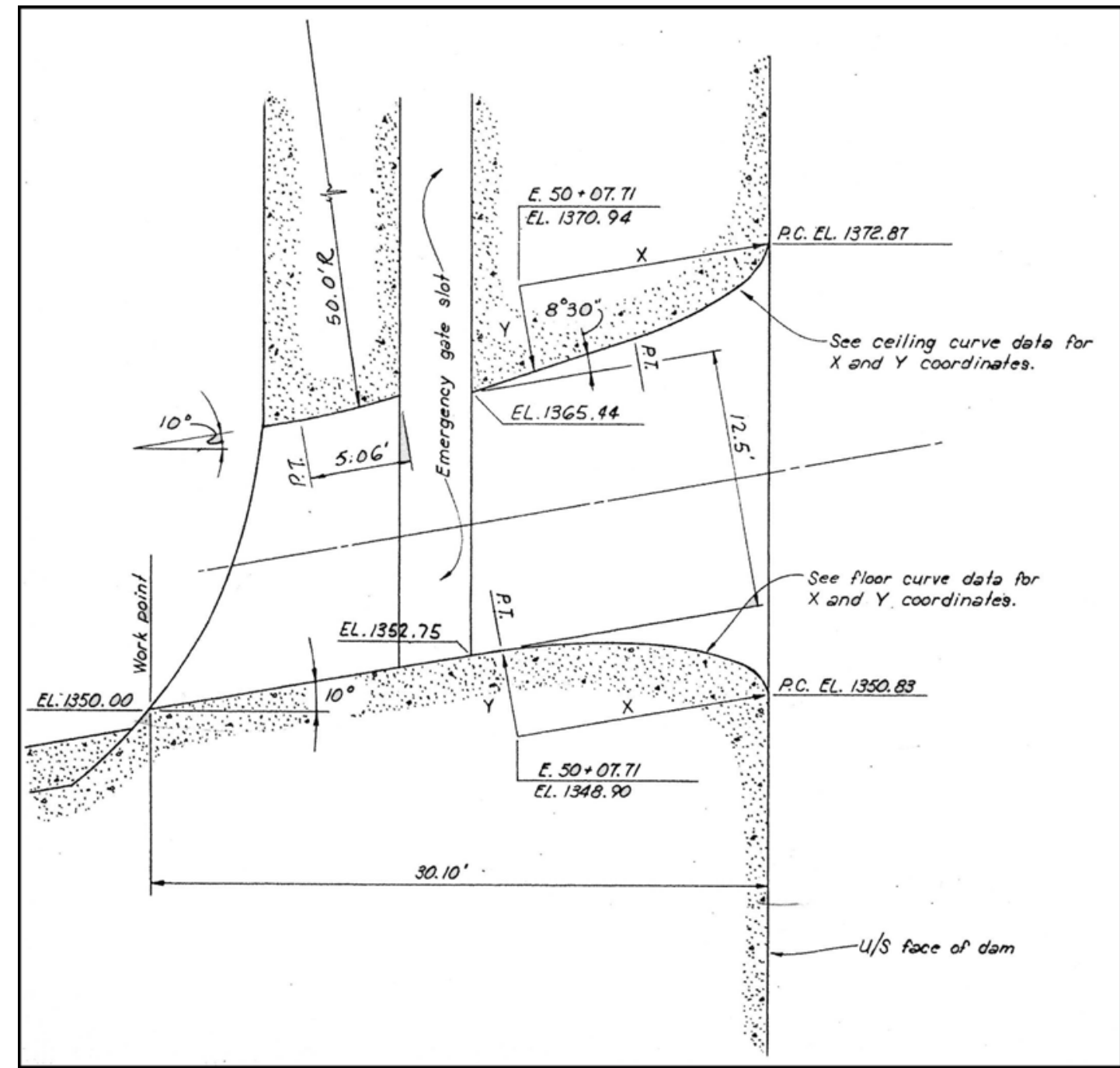

Figure 4 Vertical Side View Drawing of a Regulating Outlet. Drawing scanned from USACE engineering drawing sheet 157, file no DWD-1-4-17/26. Sheet label "Dworshak Dam and Reservoir, Outlet Works, Bellmouth Intake, Horizontal and Vertical Control”. Sheet drawn on May 2, 1967. 


\subsection{CFD Model Domain}

The extent of the three-dimensional numerical model is displayed in Figure 5. Although the ROs are fairly small structures, the domain required by the CFD model was significant (approximately $1 / 3$ of the dam width). This size of grid was required to ensure that model boundary conditions did not influence solution results. The mesh domain extent was a hexahedral, $880 \mathrm{ft}$ wide by 400 $\mathrm{ft}$ deep by $620 \mathrm{ft}$ high. The vertical extent of the mesh extended from elevation $1000 \mathrm{ft}$ to $1620 \mathrm{ft}$ MSL.

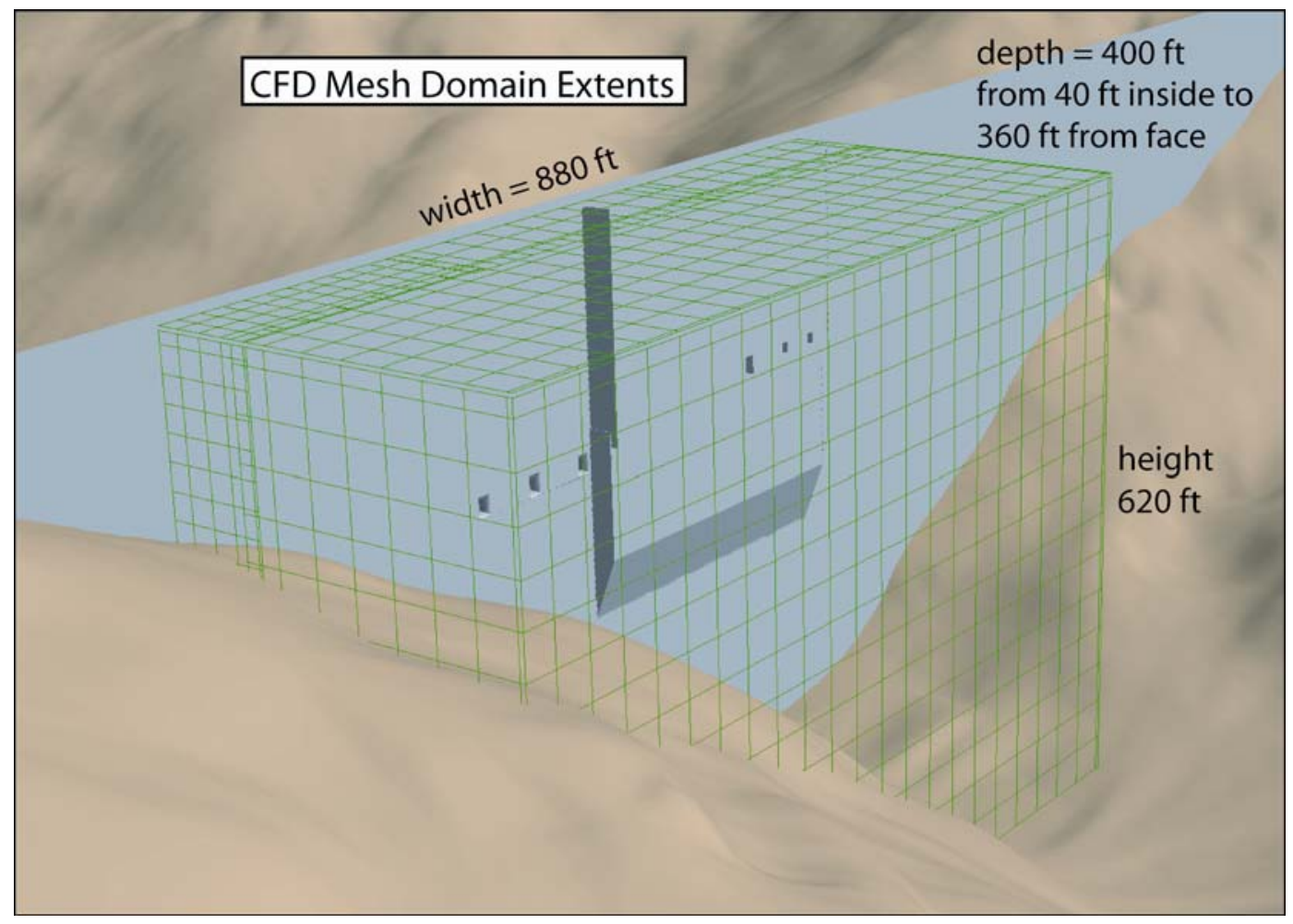

Figure 5 CFD mesh domain extent. Note: the mesh grid displayed in the figure is several times coarser than actual (see Figure 6).

The time required to compute a simulation result is directly proportional to the number of computational cells. Hence effort was put forth to construct a mesh that had sufficient resolution to capture velocity gradients and turbulence characteristics in regions of interest, yet was coarse in regions of either low velocity gradients or not of concern under the present project. The resulting mesh grid is displayed in Figure 6.

Mesh resolution was finest at $1 \mathrm{ft}$ grid cells near and inside the ROs. Upstream of the RO entrances, the grid was coarsened to a uniform $3 \mathrm{ft}$ grid. This region stretched from approximately $100 \mathrm{ft}$ upstream of each RO centerline and $100 \mathrm{ft}$ to the left of RO1 and to the right of RO3. Outside of this finer resolution region, the mesh was uniformly sized with $10 \mathrm{ft}$ grid cells. 

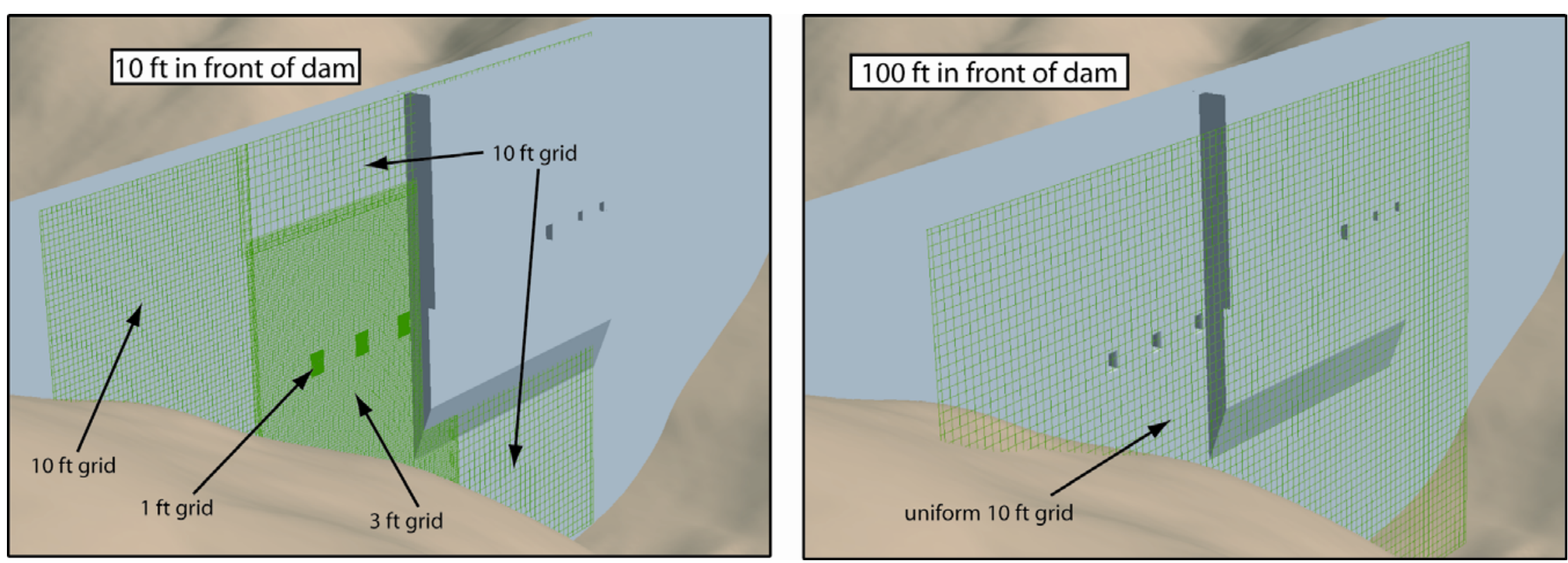

Figure 6 CFD mesh resolution. The left graphic displays the mesh resolution between the downstream boundary (40 ft inside the dam) to $100 \mathrm{ft}$ upstream of the dam face. The right graphic displays the mesh resolution from $100 \mathrm{ft}$ upstream of the dam face to the upstream CFD model boundary. 


\subsection{Numerical Model}

\subsubsection{CFD Model description}

The commercial software package Flow-3D was selected as the numerical model for simulating the ROs at Dworshak Dam. The model has a wide user base and has been previously tested and validated under a wide range of applications.

Flow-3D uses the finite volume method to solve the Reynolds-averaged Navier-Stokes (RANS) equations. The physical domain to be simulated must be decomposed into Cartesian grids composed of variable-sized hexahedral cells. The domain can either be contained within a single grid or several grids, often called "multi-blocks". If several grids are used, each grid must either be completely contained within a larger grid ("nested") or be adjacent to another grid.

For each cell, average values for the flow parameters (pressure and velocity) are computed at discrete times using a staggered grid technique (FSI, 2003). The staggered grid technique places all dependent variables at the center of each cell except for velocities, which are located at cell faces. This prevents the "checkerboard" solution that can result in incompressible flow simulations when velocities and pressures become unlinked at adjacent computational nodes (Patankar, 1980). Most terms in the equations are evaluated explicitly using the current time-level values of the local variables. Although this explicit procedure is generally efficient and well suited for free-surface wave propagation, it requires that the time-step size be limited to maintain stability requirements. Time steps for most of the Dworshak Dam simulations were on the order of $0.04 \mathrm{sec}$.

Flow-3D has several models for calculating the turbulent viscosity: Prandlt mixing length, oneequation, two-equation $\kappa-\varepsilon$ and "Renormalization Group" (RNG) $\kappa-\varepsilon$, and Large Eddy Simulation (LES). These typically robust turbulence models have been well tested and documented in the relevant technical literatures. Based upon prior experience with Flow-3D and the size of the domain, the RNG $\kappa-\varepsilon$ model was selected for all simulations.

The RNG model applies statistical methods for a derivation of the averaged equations for turbulence quantities, such as turbulent kinetic energy and dissipation rate. The RNG model also relies less on empirical constants versus the standard $\kappa-\varepsilon$ model. Details on the turbulence model can be found in Yakhot and S.A.Orszag (1986), Yakhot and L.M.Smith (1992) and Yakhot et al. (1992).

\subsubsection{Boundary Conditions and Assumptions}

Flow-3D uses a technique called the Fractional Area/Volume Obstacle Representation (FAVOR) technique to define solids within the model domain (FSI, 2003). Unlike the finite element or another type of boundary fitted CFD model, the FAVOR technique requires the user to first define a bounding hexahedral shape (see Figure 5 above). Then, inside of this hexahedron, the dam structure and bathymetry are imported and placed to define solid objects. The model determines at the onset of each simulation which cells within the hexahedron are fully "blocked" and does not solve the equations of motion within these cells.

Boundary conditions must be specified along all faces of the bounding hexahedral domain shown in Figure 5. Along the most upstream face a pressure boundary and a water surface elevation was specified, allowing flow to smoothly enter the domain. The side boundaries were symmetry planes of velocity magnitude, which forces water to only flow parallel to these faces. The bottom boundary was the bathymetry and the top boundary was also a symmetry plane. Although Flow- 
$3 \mathrm{D}$ is capable of simulating free-surface flows, a rigid lid was placed at the top boundary to suppress waves that may form along the water surface during model warm-up.

Several key assumptions implied by specifying these boundary conditions are: 1) there is zero ambient flow in the lake and all flow entering the upstream pressure boundary starts from rest, 2) the powerhouse turbine units are off and zero flow is passing through the powerhouse penstock intakes, and 3) the lake was thermally homogenous. The first assumption was necessary because observed velocity data from the forebay was unavailable at the time of this study. If observed field data becomes available, alternative boundary conditions, such as specified velocity vectors for both the upstream and side boundaries of the domain, may be more appropriate. The second assumption was made for simplicity, and may be altered if desired for future simulations. Before the powerhouse intakes could be simulated however, the selective withdrawal structures would need to be incorporated into the CFD model grid. The third assumption ignores any influence of stratification on water motions within the lake. This assumption was based upon 2002 water profile data (Carroll and Barkow, 2003), which showed that at elevations below the thermocline water temperatures in the lake were relatively uniform. Since the upper entrance of the ROs are at elevation $1373 \mathrm{ft}$ (approximately $100 \mathrm{ft}$ to $200 \mathrm{ft}$ beneath the water surface), these low level outlets are generally below the thermocline and withdrawal characteristics are not expected to change due to upper water column stratification. If future modeling of the selector gates is performed this assumption could easily be changed within the numerical model. 


\subsection{Computational Modeling Scenarios}

Twenty-four separate simulations were performed under the scope of this project. These simulations fall into four water surface elevation groups: $1460 \mathrm{ft}, 1500 \mathrm{ft}, 1560 \mathrm{ft}$, and $1600 \mathrm{ft}$ MSL (see Table 1). For each water surface elevation, the tainter gate valves were opened either 1 $\mathrm{ft}$ or $10 \mathrm{ft}$. In addition, for each unique combination of water surface elevation and valve opening, either one (center RO2 only), two (RO1 and RO 3 only), or all three ROs were operating. This pattern of tainter valve operation follows the strict operational rules for Dworshak Dam, and is required for smooth passage of flow down the spillway face.

Table 1 Matrix of simulations performed during the project.

\section{Dworshak RO Simulations}

\begin{tabular}{|c|c|c|c|c|c|}
\hline Run \# & Elevation & Gate Opening & ROs Open & Discharge/bay & Total \\
\hline 2 & 1460 & 1 & center & 600 & 600 \\
\hline 3 & 1460 & 1 & ends & 600 & 1,200 \\
\hline 4 & 1460 & 1 & all three & 600 & 1,800 \\
\hline 5 & 1460 & 10 & center & 5,650 & 5,650 \\
\hline 6 & 1460 & 10 & ends & 5,650 & 11,300 \\
\hline 7 & 1460 & 10 & all three & 5,650 & 16,950 \\
\hline 8 & 1500 & 1 & center & $\overline{700}$ & 700 \\
\hline 9 & 1500 & 1 & ends & 700 & 1,400 \\
\hline 10 & 1500 & 1 & all three & 700 & 2,100 \\
\hline 11 & 1500 & 10 & center & 6,700 & 6,700 \\
\hline 12 & 1500 & 10 & ends & 6,700 & 13,400 \\
\hline 13 & 1500 & 10 & all three & 6,700 & 20,100 \\
\hline 14 & 1560 & 1 & center & 850 & 850 \\
\hline 15 & 1560 & $\overline{1}$ & ends & 850 & 1,700 \\
\hline 16 & 1560 & 1 & all three & 850 & 2,550 \\
\hline 17 & 1560 & 10 & center & 8,100 & 8,100 \\
\hline 18 & 1560 & 10 & ends & 8,100 & 16,200 \\
\hline 19 & 1560 & 10 & all three & 8,100 & 24,300 \\
\hline 20 & 1600 & 1 & center & 950 & 950 \\
\hline 21 & 1600 & 1 & ends & 950 & 1,900 \\
\hline 22 & 1600 & 1 & all three & 950 & 2,850 \\
\hline 23 & 1600 & 10 & center & 9,100 & 9,100 \\
\hline 24 & 1600 & 10 & ends & 9,100 & 18,200 \\
\hline 1 & 1600 & 10 & all three & 9,100 & 27,300 \\
\hline
\end{tabular}

This wide range of water surface elevations, number of ROs open, and tainter gate valve openings produced a dynamic range of water velocities in the forebay. This range is illustrated graphically in Figures 7 and 8 below. 


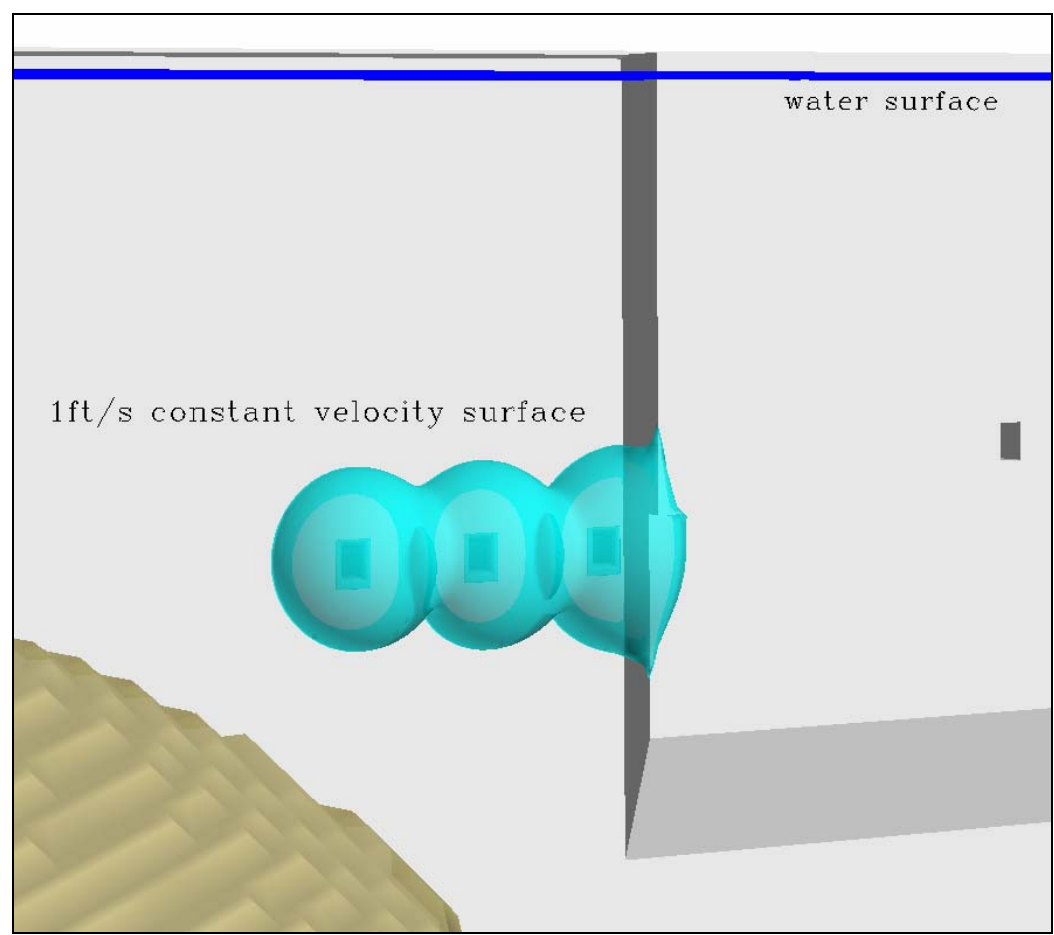

Figure 7 Simulation results for Run 1. Brown is bathymetry, forebay water surface elevation is 1600 $\mathrm{ft}$, all three ROs are open, tainter valves are open $10 \mathrm{ft}$, discharge per bay is $9,100 \mathrm{cfs}$, and the total discharge is $27,300 \mathrm{cfs}$.



Figure 8 Simulation results for Run 2. Brown is bathymetry, forebay elevation is $1460 \mathrm{ft}$, only the center ROs is open, tainter valve is open $1 \mathrm{ft}$, discharge for the center bay is $600 \mathrm{cfs}$, and the total discharge is $600 \mathrm{cfs}$. 


\subsection{Results and Future Directions}

Simulation results presented in Appendix A display velocity magnitude contour plots and X-Y graphs of velocity magnitude versus distance from the dam face. The upper graphic on each page displays results along a horizontal slice placed at elevation $1360 \mathrm{ft}$ (approximate RO centerline). Contours have been placed at $1 \mathrm{ft} / \mathrm{s}$ increments, between 1 and $10 \mathrm{ft} / \mathrm{s}$ (note: the $1 \mathrm{ft} / \mathrm{s}$ contour is the most upstream contour shown in every figure).

The center graphic on each appendix page displays simulation results along the vertical centerline in front of each RO. As for the horizontal contours, vertical slice contours of velocity magnitude have been placed at $1 \mathrm{ft} / \mathrm{s}$ increments, between 1 and $10 \mathrm{ft} / \mathrm{s}$ (the farthest upstream is the $1 \mathrm{ft} / \mathrm{s}$ contour). Black arrows have been placed in all contour plots at the entrance to each RO. These arrows indicate the general flow direction if that particular RO was operating; they were not scaled to represent velocity magnitude and have been placed at each entrance whether that particular RO is operating or not for a specific simulation.

X-Y graphs of simulation results are presented on each page in Appendix A. Data displayed in these graphs were constructed by sampling model results along a horizontal line extending out from the dam face, starting at each RO intake center point.

As expected, water velocity magnitudes at the same distance away from the dam face increase dramatically with larger tainter gate valve openings. Velocity contour lines have been shown between 1 and $10 \mathrm{ft} / \mathrm{s}$ in the appendix figures. The location of small magnitude velocity contour lines (i.e., contours less than $3 \mathrm{ft} / \mathrm{s}$ ) could vary dramatically based upon ambient lake velocities, powerhouse operations, and thermal stratification.

One recommendation to improve simulation results would be to confirm the underlying assumptions used when constructing the numerical model. A method to confirm these assumptions would be to collect of water velocity and temperature data in the forebay while the ROs are operating. A second recommendation for model improvement would be to include the selective withdrawal structure into the model and to simulate concurrent powerhouse operations with RO operation. At present the impact of these assumptions are unknown, however experience suggests that they could impact the location of the contour lines shown in the appendix; especially smaller velocity magnitude contour lines. Likewise, the location of larger velocity magnitude contour lines would be expected to move less due to these assumptions as they are more directly influenced by RO operations. 


\subsection{References}

Carrol, J and K. Barkow (2003) Preliminary Water Quality, Meteorological, Operations, and Flow Data for the Snake River System. Carrol J. and K. Barkow, eds., U.S. Army Corps of Engineers, March.

FSI (2003). Flow-3D User's Manual. Flow Science, Inc., Sante Fe, NM.

Patankar, S. (1980). Numerical Heat Transfer and Fluid Flow. Hemisphere, New York, New York.

USACE (1986). Water Control Manual for Dworshak Dam and Reservoir, North Fork Clearwater River, Idaho. U.S. Army Corps of Engineers, Walla Walla District, November.

Yakhot, V., and L.M.Smith (1992). The Renormalization Group, the e-Expansion and Derivation of Turbulence Models. J. Scientific Computing, 7:35-61.

Yakhot, V., S. Orszag, S. Thangam, T. Gatski, and C. Speziale, 1992. Development of turbulence models for shear flows by a double expansion technique. Phys. Fluids, A4(7):1510-1520.

Yakhot, V., and S.A.Orszag, 1986. Renormalization Group Analysis of Turbulence. I. Basic Theory. J. Scientific Computing, 1:1-51. 
Appendix A. Velocity Magnitude Simulation Results 


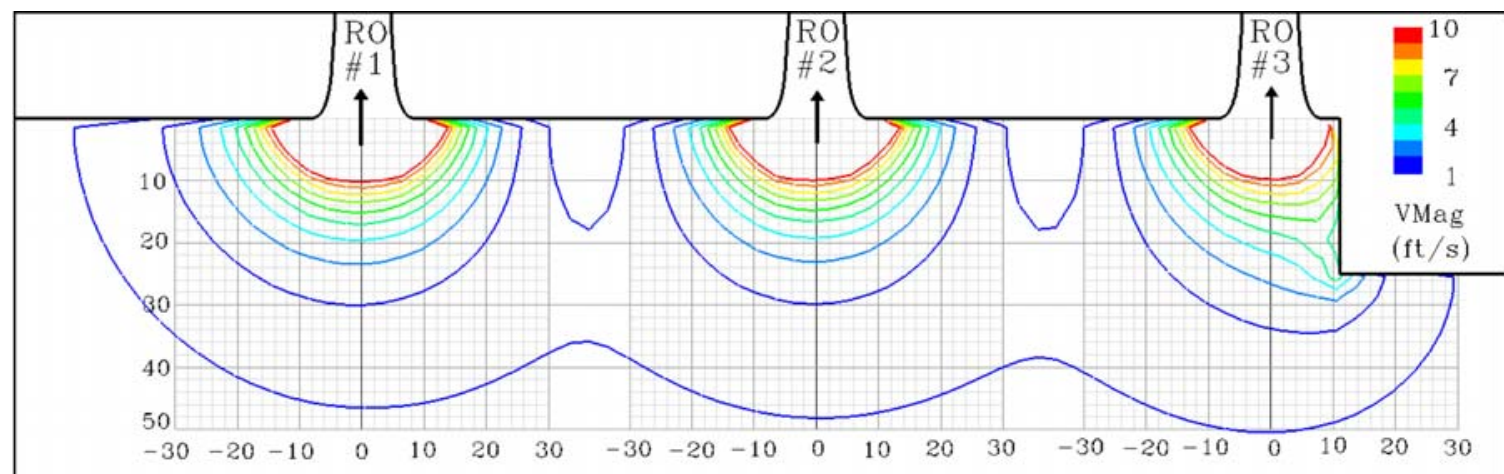

Plan View - Horizontal Slice at Elevation $1360 \mathrm{ft}$ - Axes units in ft.



Side View - Vertical Slices along RO Centerlines - Axes units in ft.

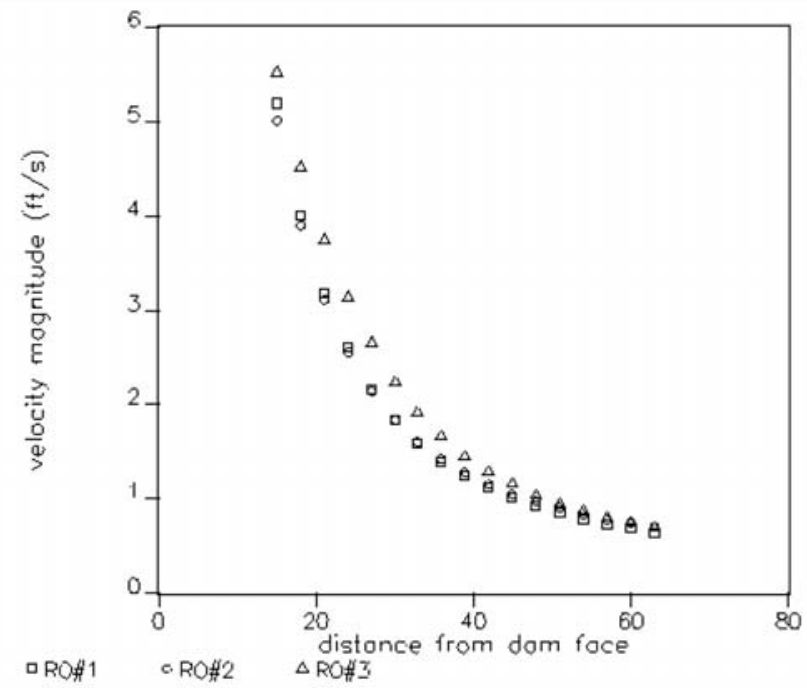

Run \#01

$\mathrm{WSE}=1600 \mathrm{ft}$

RO \# $1=9100 \mathrm{cfs}$

RO \# $2=9100 \mathrm{cfs}$

RO \# $3=9100 \mathrm{cfs}$ 


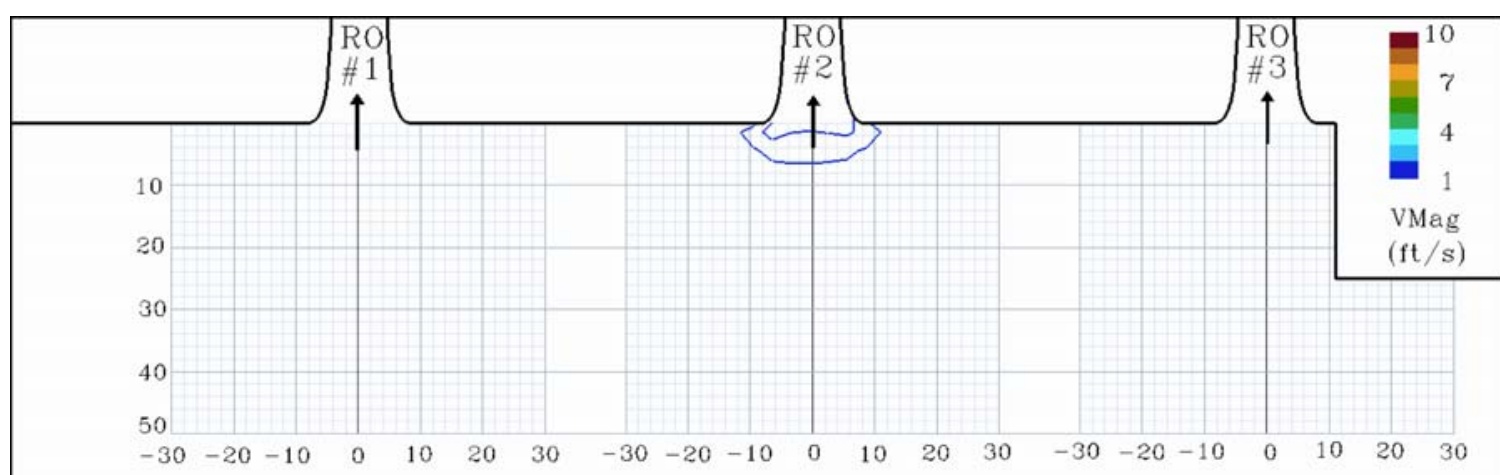

Plan View - Horizontal Slice at Elevation $1360 \mathrm{ft}$ - Axes units in ft.



Side View - Vertical Slices along RO Centerlines - Axes units in ft.



Run \#02

$\mathrm{WSE}=1460 \mathrm{ft}$

RO \# $1=0 \mathrm{cfs}$

RO \# $2=600 \mathrm{cfs}$

RO \# $3=0 \mathrm{cfs}$ 


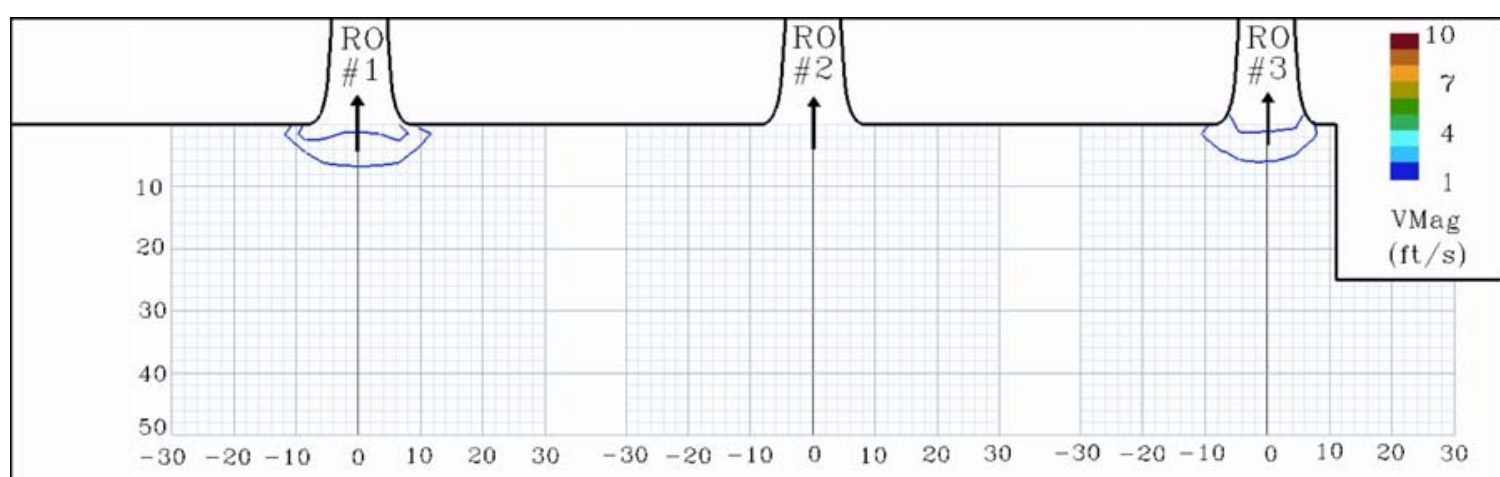

Plan View - Horizontal Slice at Elevation $1360 \mathrm{ft}$ - Axes units in ft.

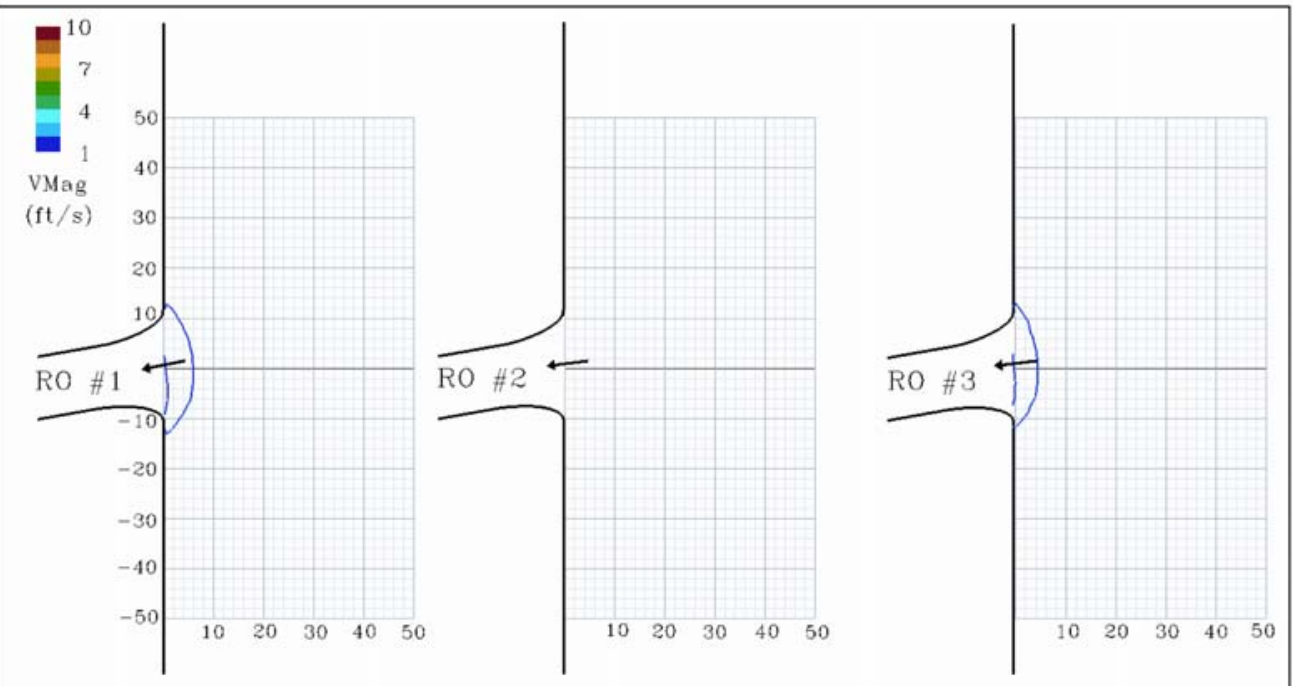

Side View - Vertical Slices along RO Centerlines - Axes units in ft.

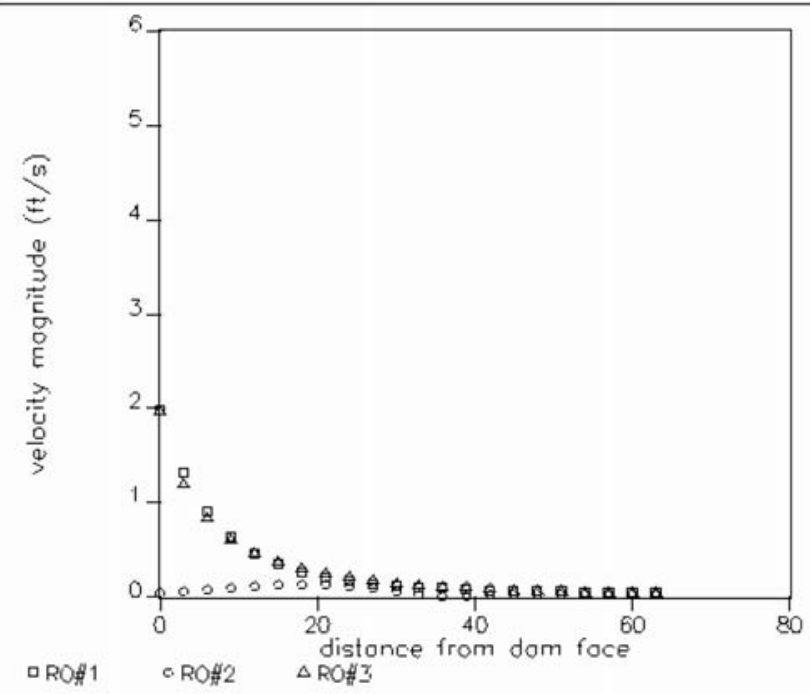

Run \#03

$\mathrm{WSE}=1460 \mathrm{ft}$

RO \# $1=600 \mathrm{cfs}$

RO \# $2=0 \mathrm{cfs}$

RO \# 3 = $600 \mathrm{cfs}$ 


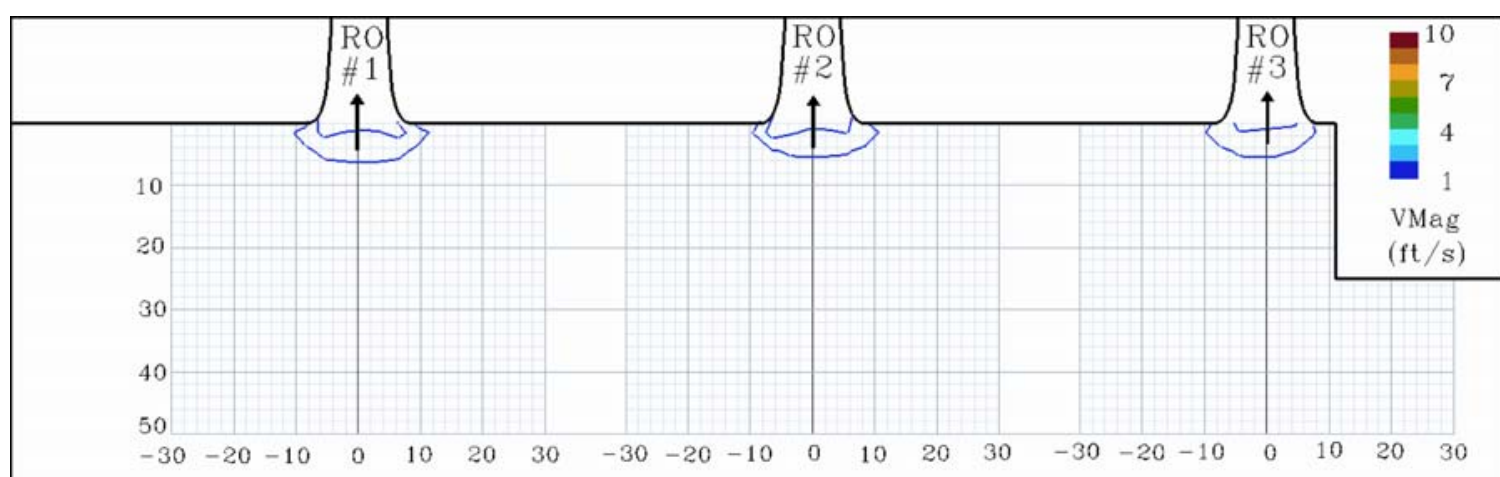

Plan View - Horizontal Slice at Elevation $1360 \mathrm{ft}$ - Axes units in ft.

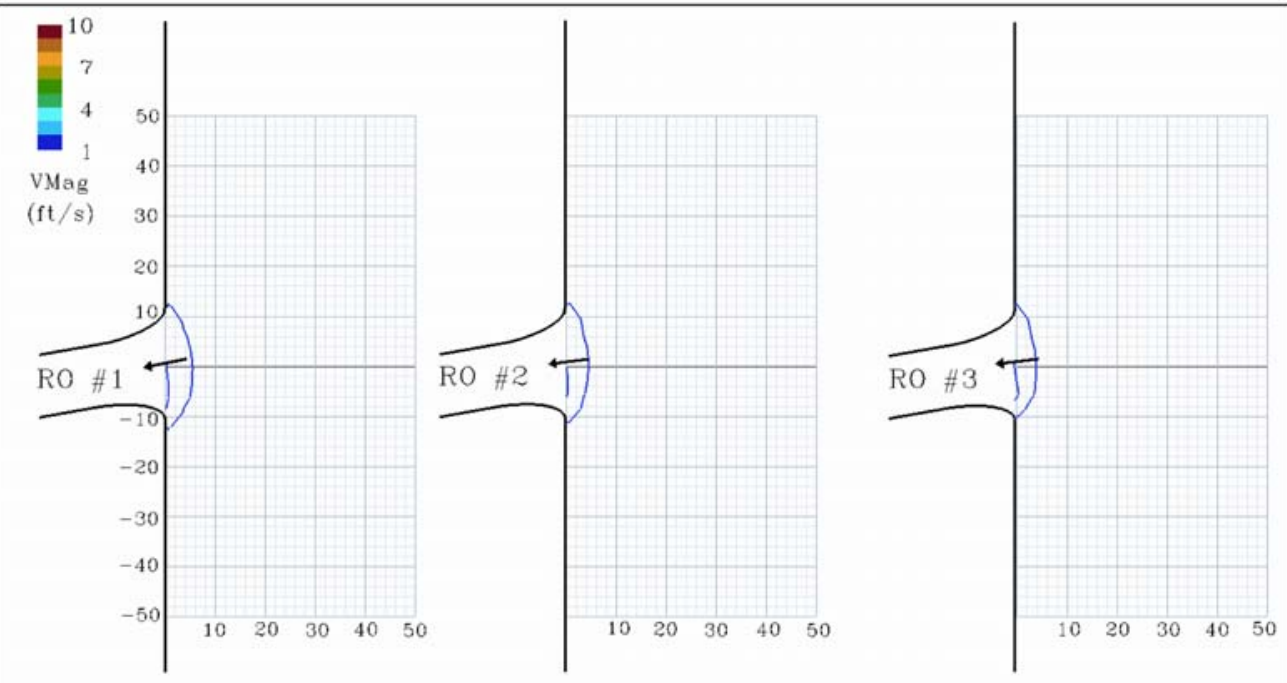

Side View - Vertical Slices along RO Centerlines - Axes units in ft.

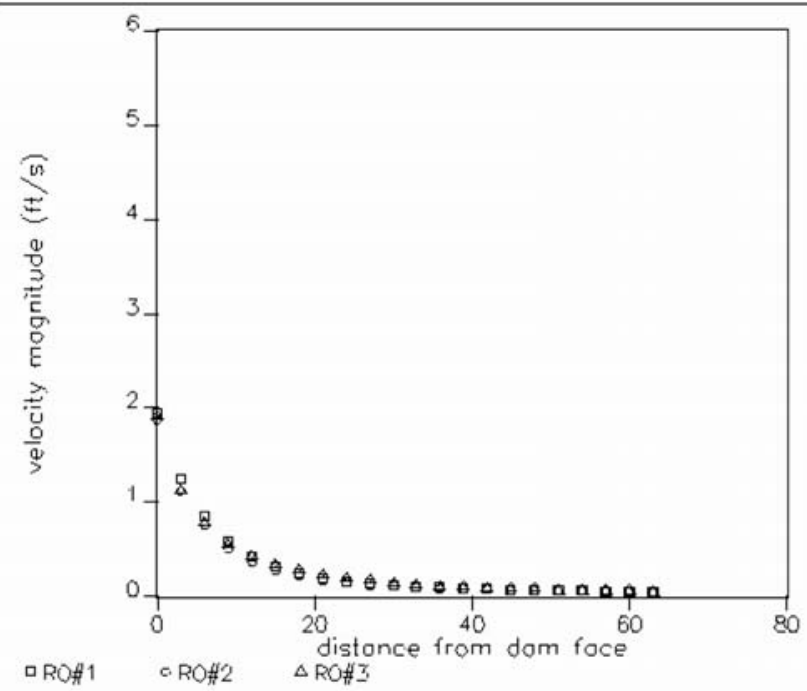

Run \#04

$\mathrm{WSE}=1460 \mathrm{ft}$

RO \# $1=600 \mathrm{cfs}$

$\mathrm{RO} \# 2=600 \mathrm{cfs}$

$\mathrm{RO} \# 3=600 \mathrm{cfs}$ 


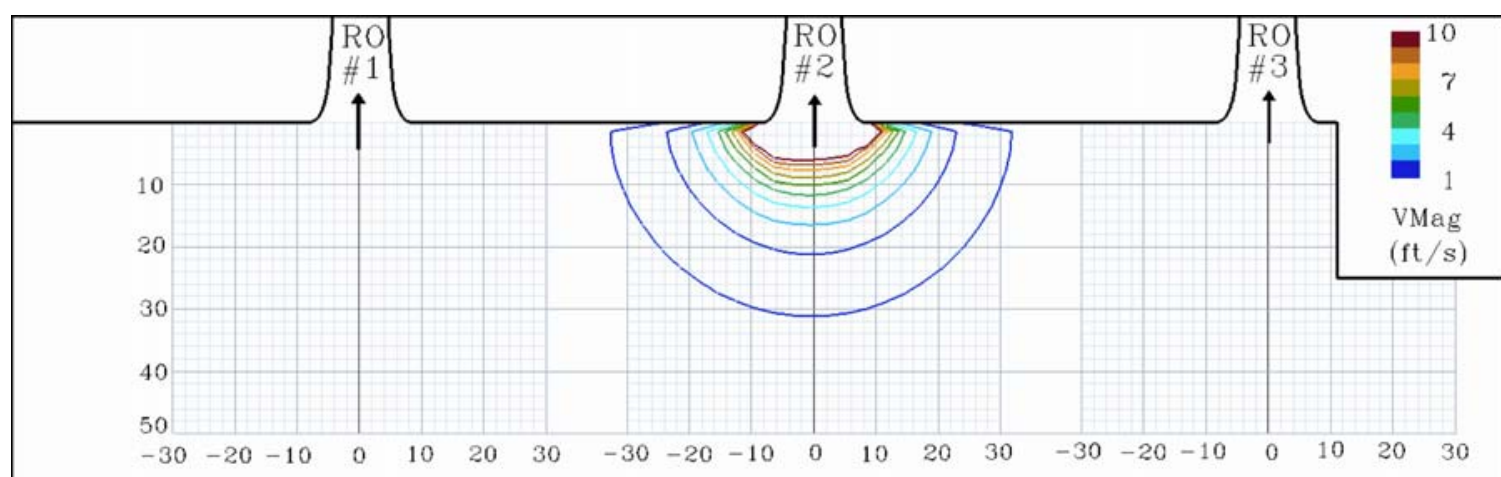

Plan View - Horizontal Slice at Elevation $1360 \mathrm{ft}$ - Axes units in ft.

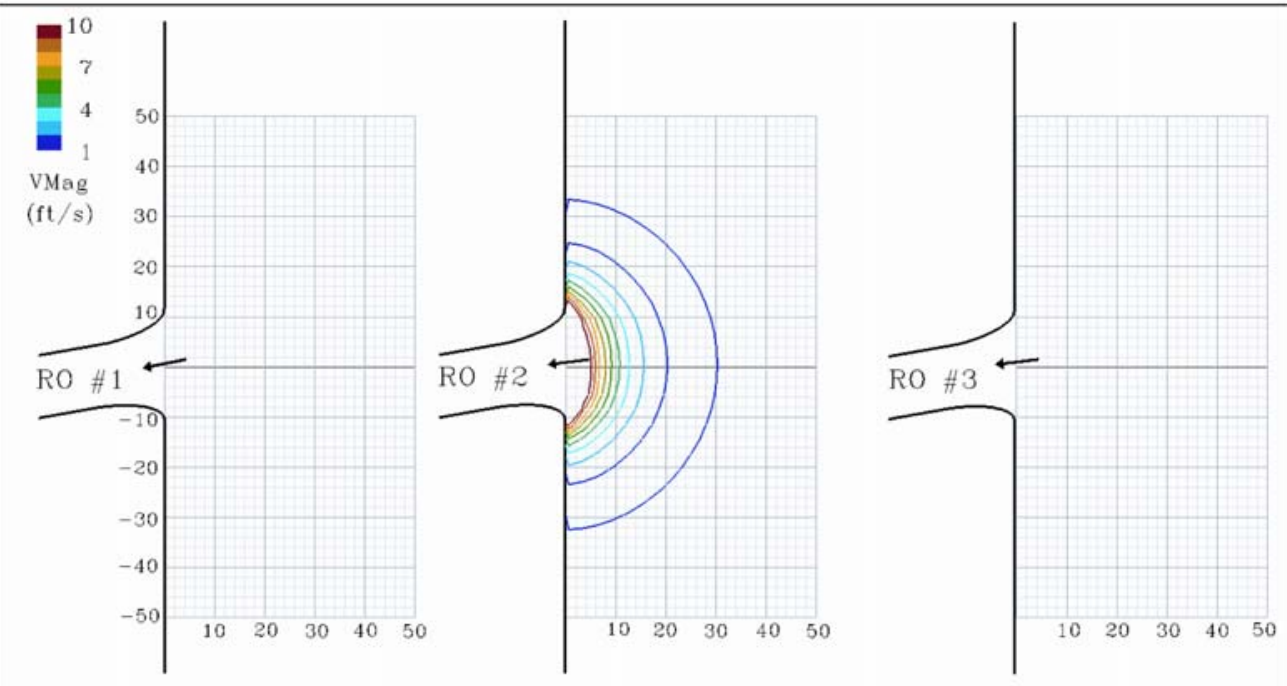

Side View - Vertical Slices along RO Centerlines - Axes units in ft.

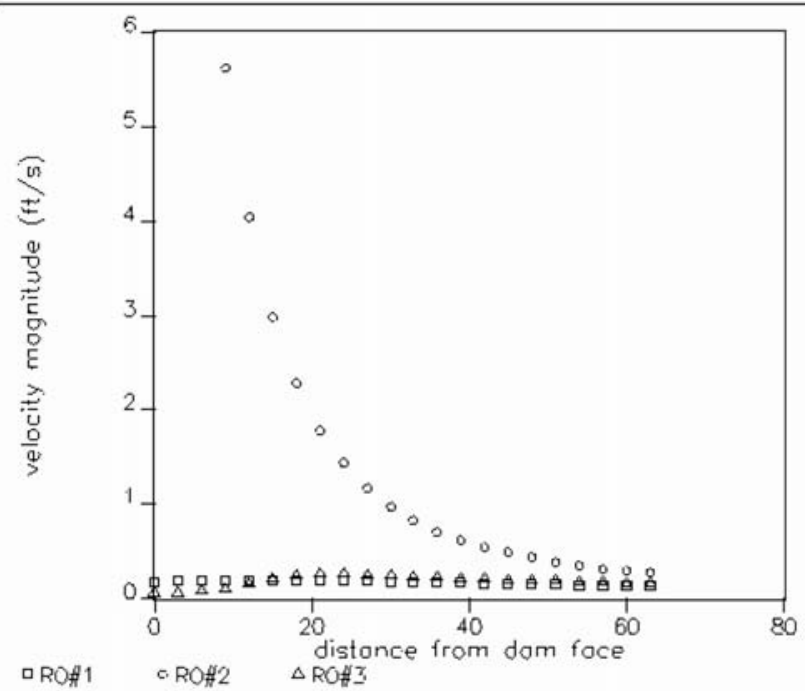

Run \#05

$\mathrm{WSE}=1460 \mathrm{ft}$

RO \# $1=0 \mathrm{cfs}$

RO \# $2=5650 \mathrm{cfs}$

RO \# $3=0$ cfs 


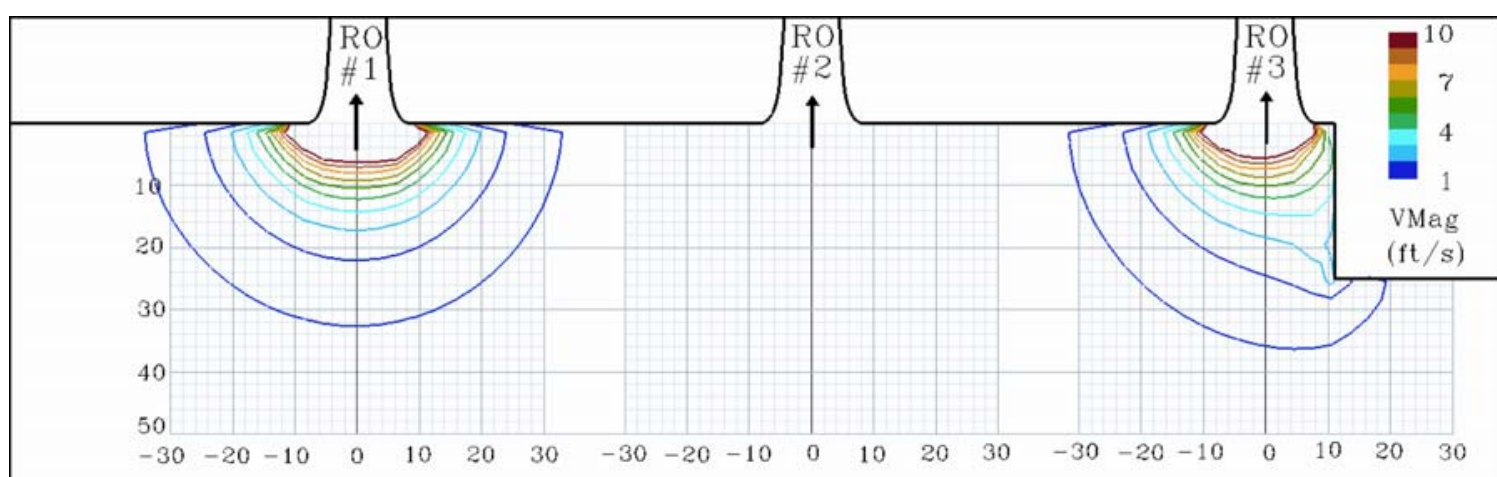

Plan View - Horizontal Slice at Elevation $1360 \mathrm{ft}$ - Axes units in ft.

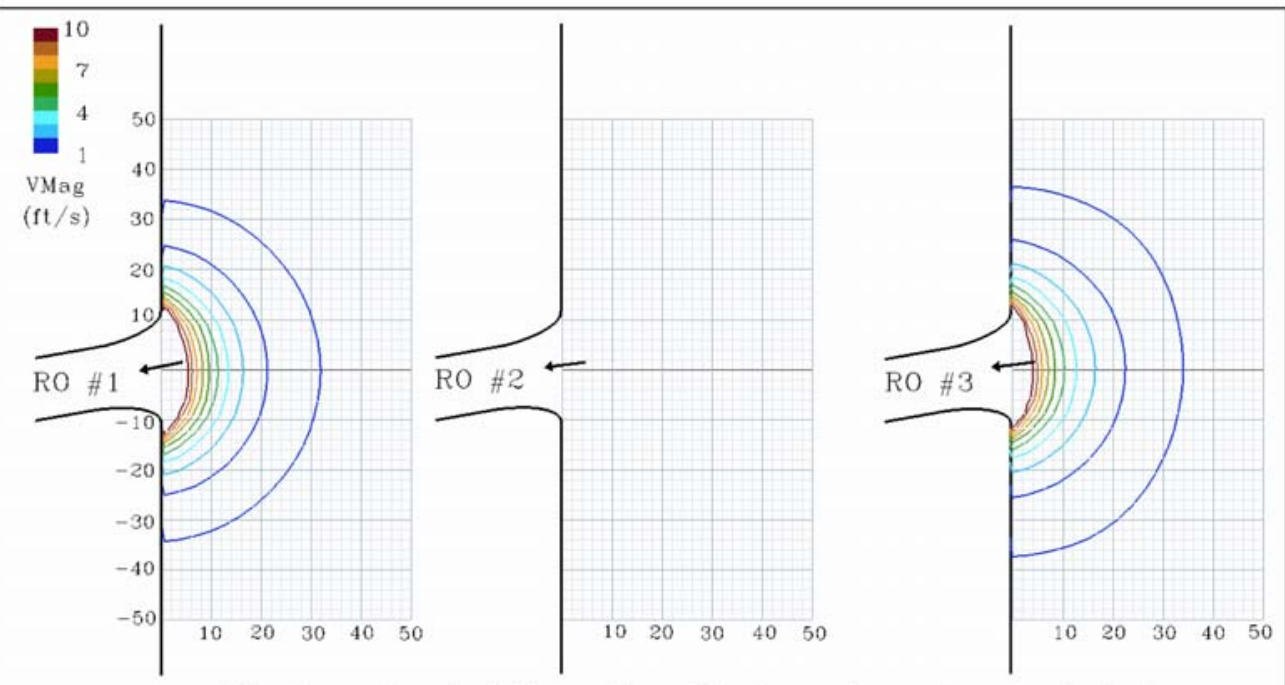

Side View - Vertical Slices along RO Centerlines - Axes units in ft.

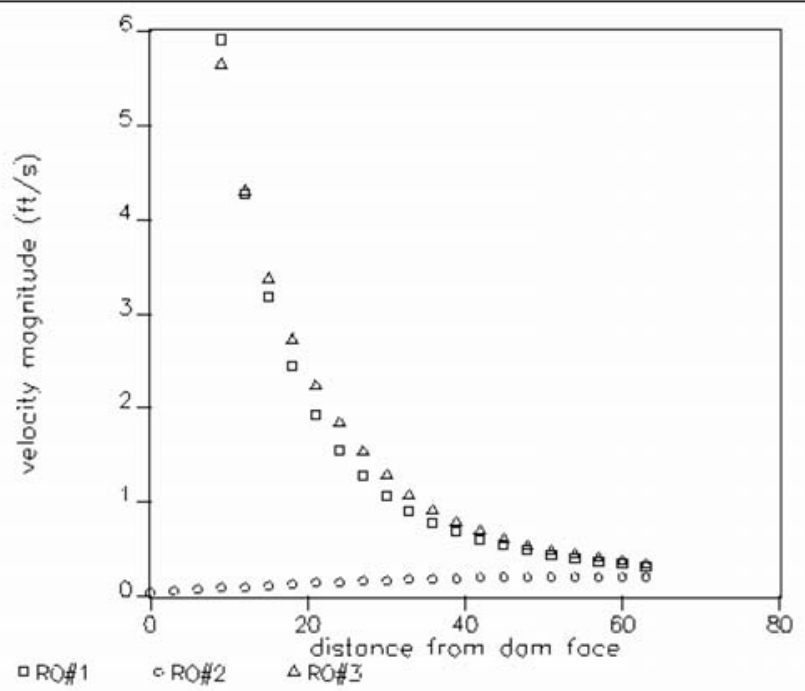
Run \#06
$\mathrm{WSE}=1460 \mathrm{ft}$
$\mathrm{RO} \# 1=5650 \mathrm{cfs}$
$\mathrm{RO} \# 2=0 \mathrm{cfs}$
$\mathrm{RO} \# 3=5650 \mathrm{cfs}$ 




Plan View - Horizontal Slice at Elevation $1360 \mathrm{ft}$ - Axes units in ft.

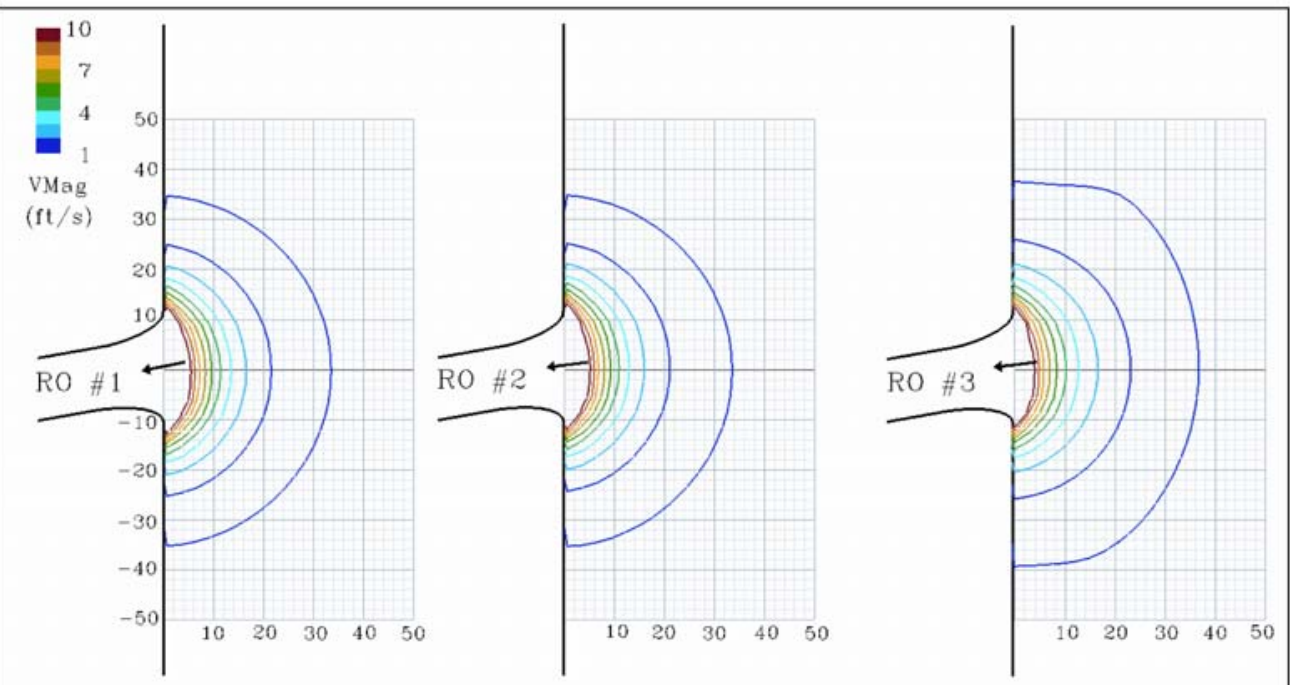

Side View - Vertical Slices along RO Centerlines - Axes units in ft.



Run \#07

$\mathrm{WSE}=1460 \mathrm{ft}$

RO \# $1=5650 \mathrm{cfs}$

$\mathrm{RO} \# 2=5650 \mathrm{cfs}$

RO \# $3=5650 \mathrm{cfs}$ 


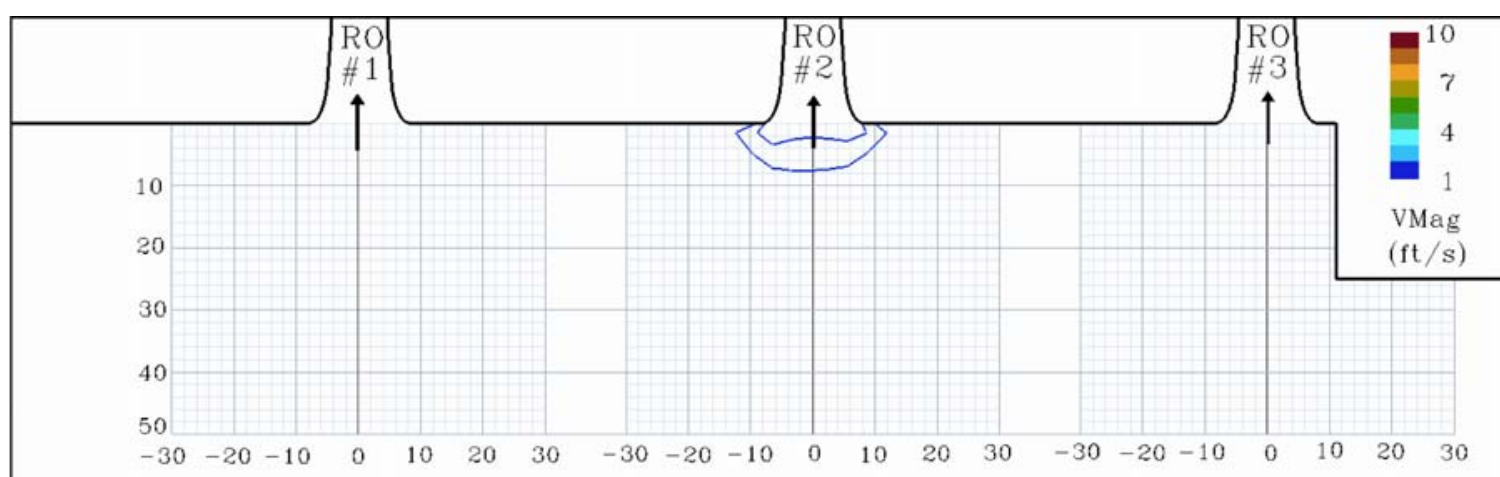

Plan View - Horizontal Slice at Elevation $1360 \mathrm{ft}$ - Axes units in ft.

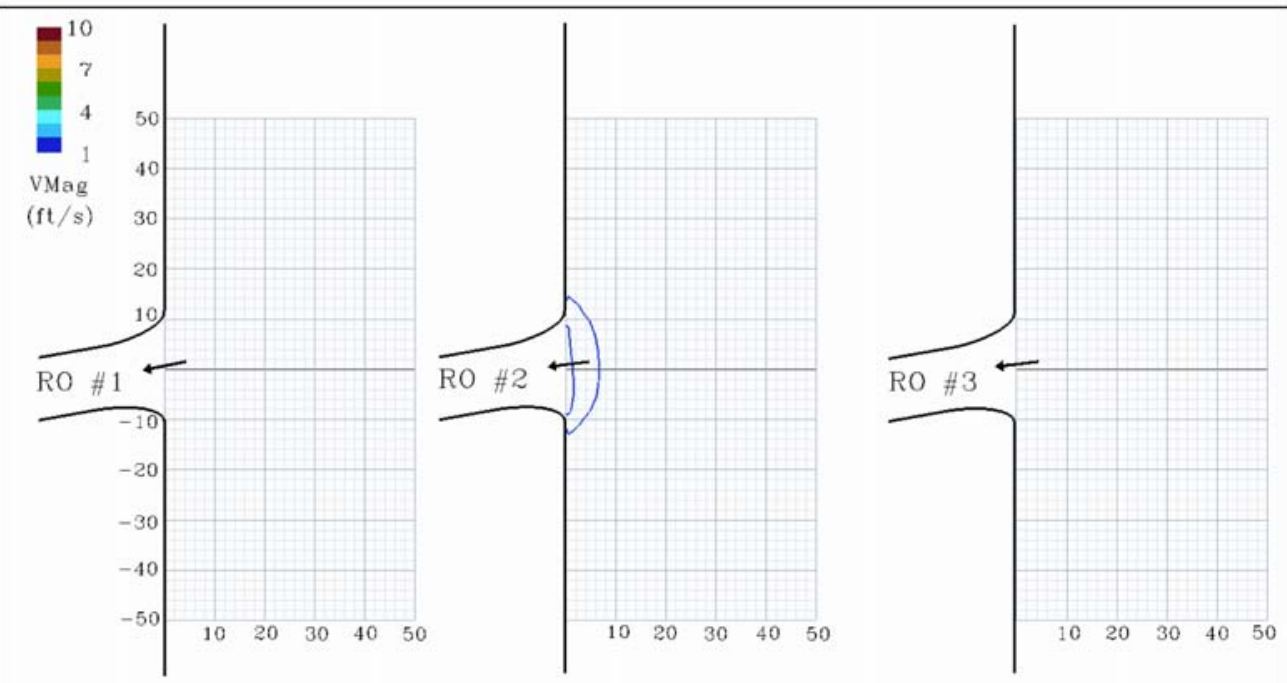

Side View - Vertical Slices along RO Centerlines - Axes units in ft.

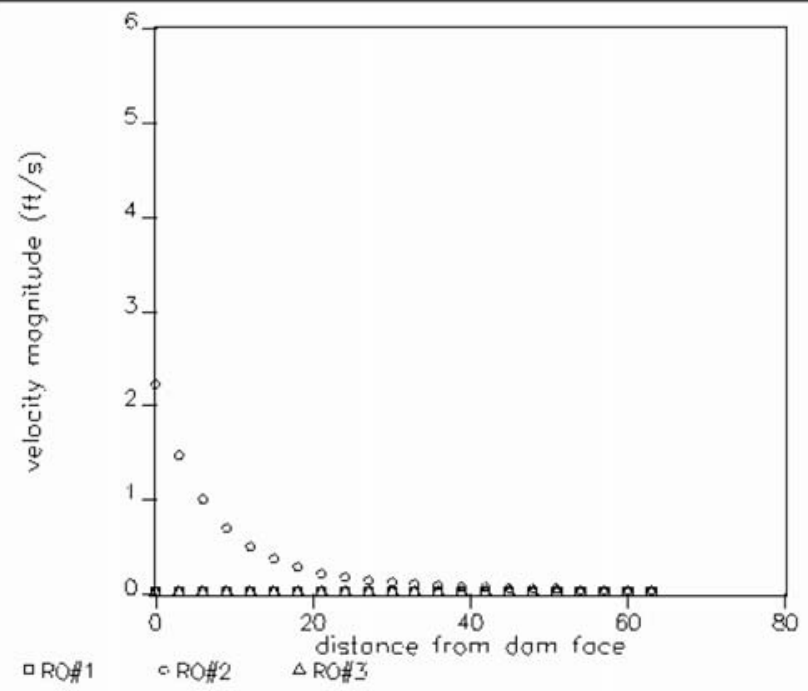

Run \#08

$\mathrm{WSE}=1500 \mathrm{ft}$

RO \# $1=0 \mathrm{cfs}$

$\mathrm{RO} \# 2=700 \mathrm{cfs}$

RO \# $3=0 \mathrm{cfs}$ 


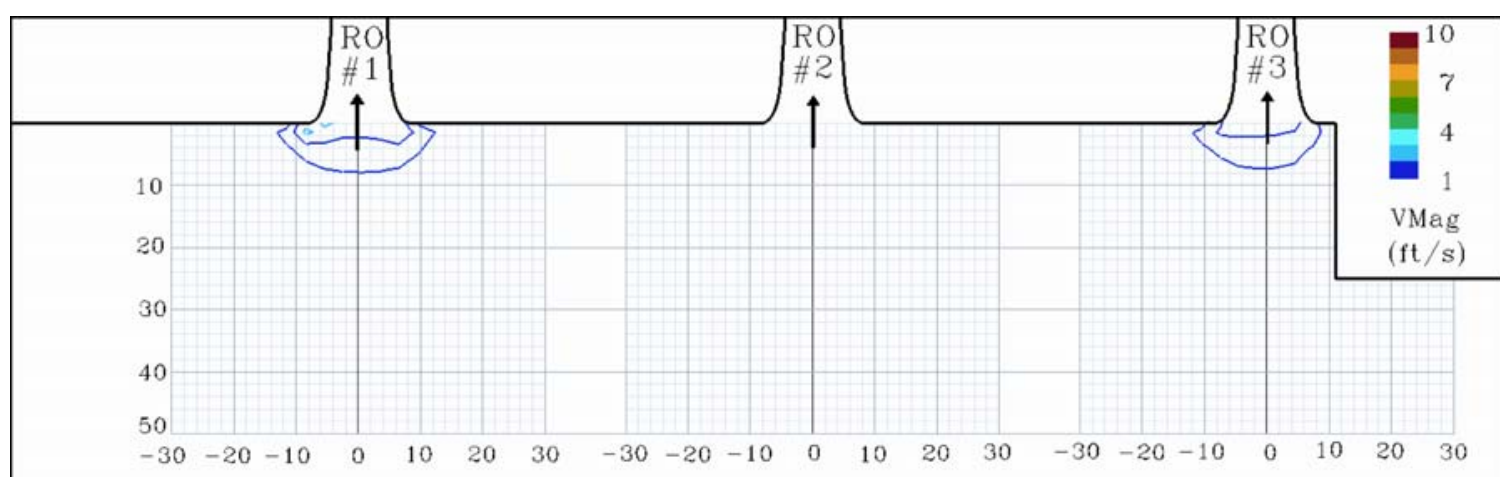

Plan View - Horizontal Slice at Elevation $1360 \mathrm{ft}$ - Axes units in ft.

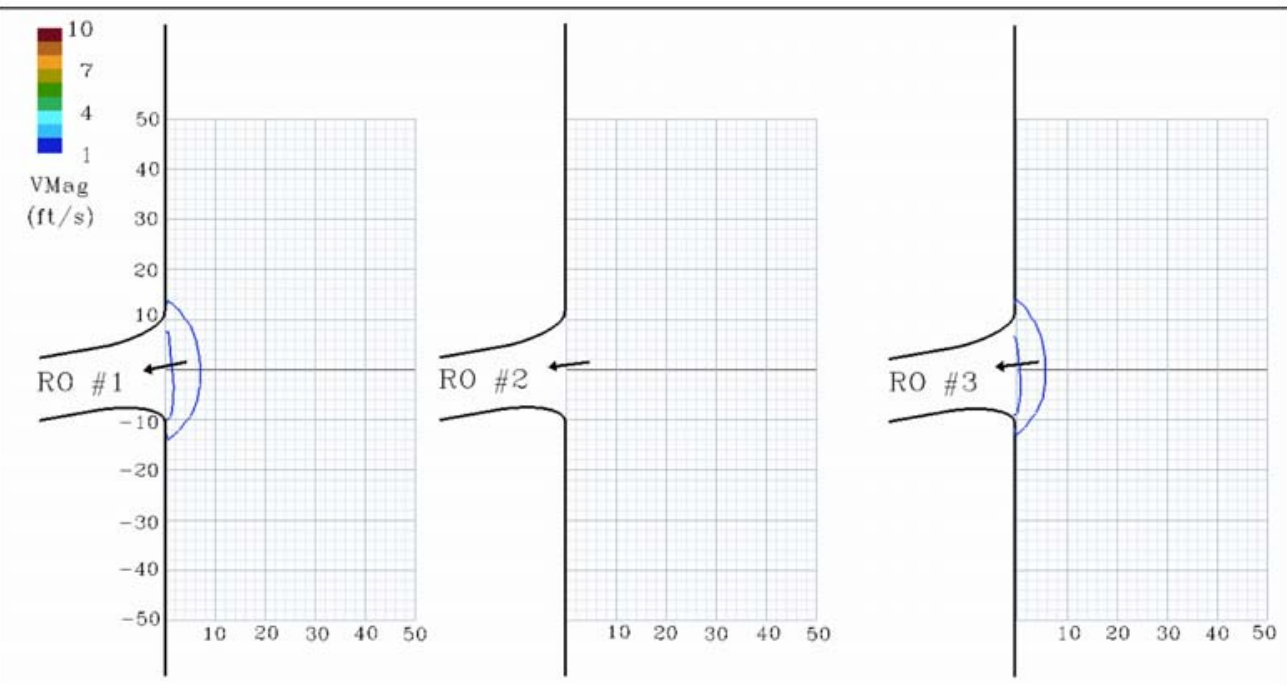

Side View - Vertical Slices along RO Centerlines - Axes units in ft.

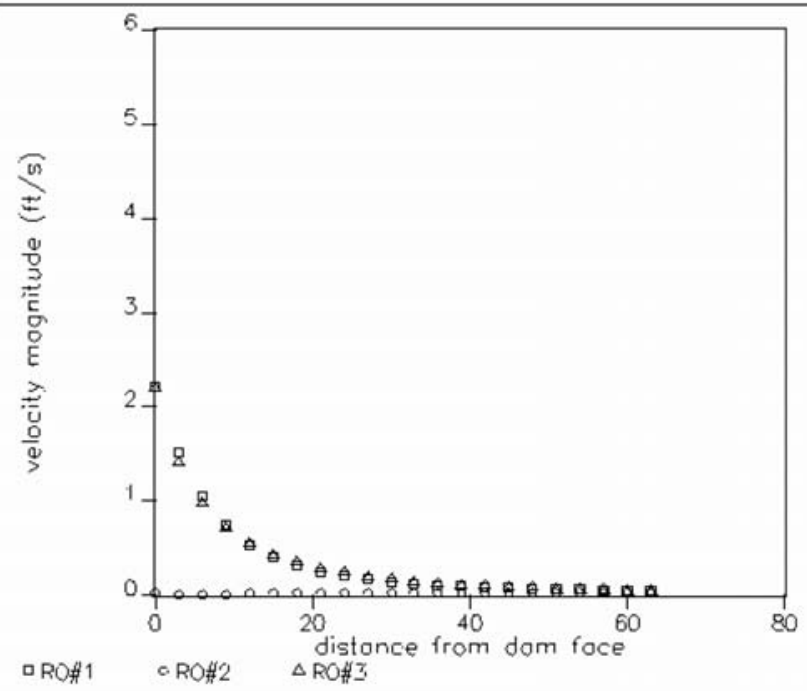
Run \#09
$\mathrm{WSE}=1500 \mathrm{ft}$
$\mathrm{RO} \# 1=700 \mathrm{cfs}$
$\mathrm{RO} \# 2=0 \mathrm{cfs}$
$\mathrm{RO} \# 3=700 \mathrm{cfs}$ 


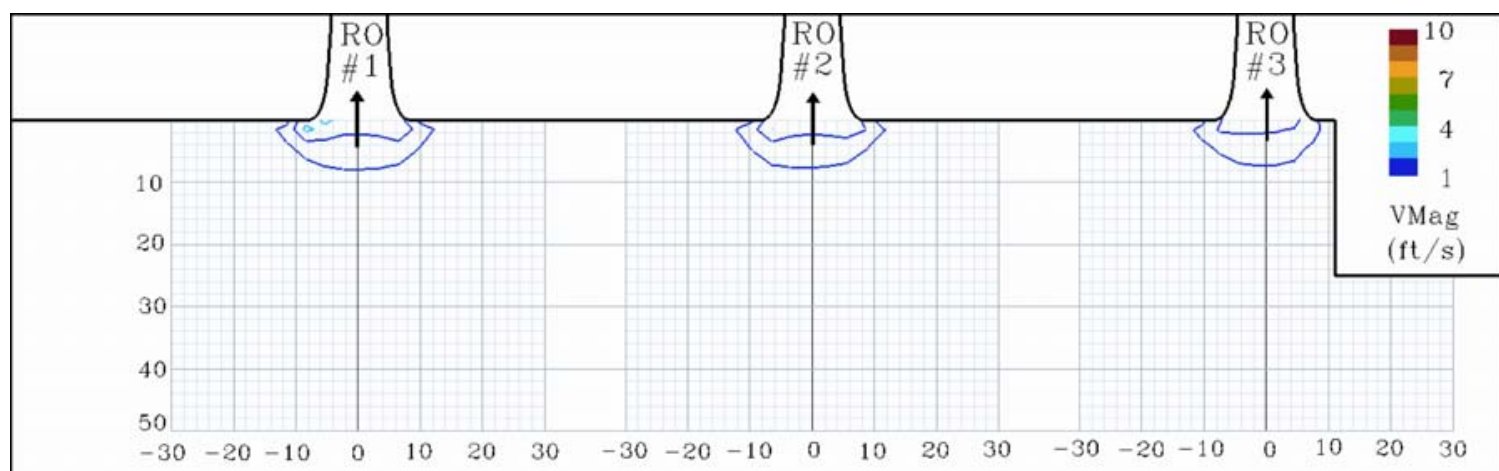

Plan View - Horizontal Slice at Elevation $1360 \mathrm{ft}$ - Axes units in ft.

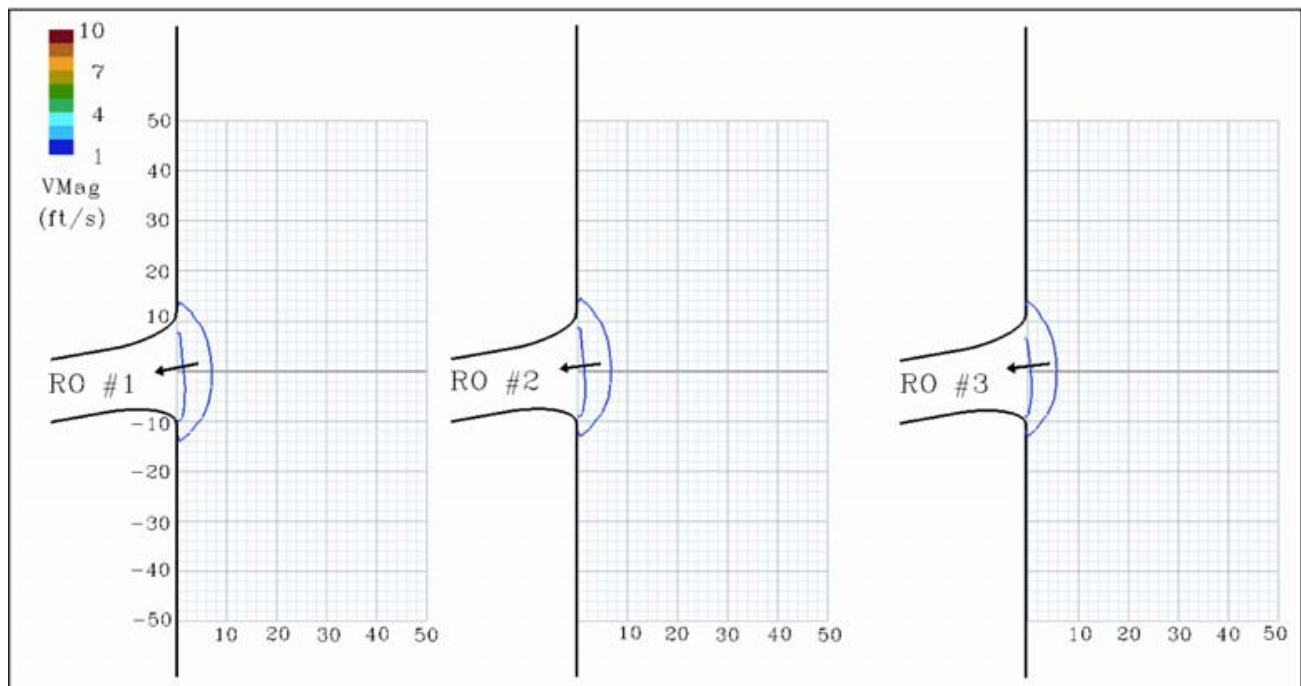

Side View - Vertical Slices along RO Centerlines - Axes units in ft.

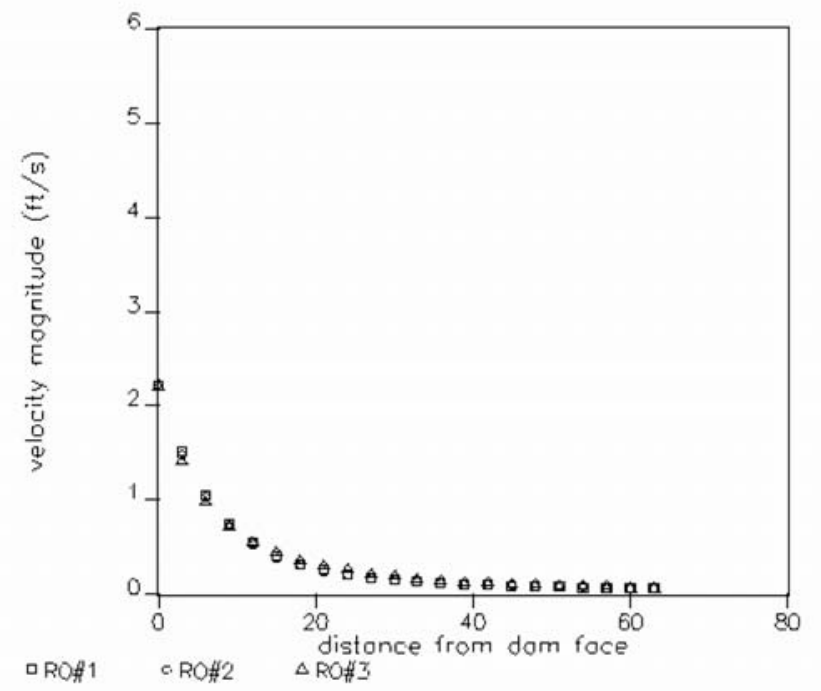
Run \#10
$\mathrm{WSE}=1500 \mathrm{ft}$
$\mathrm{RO} \# 1=700 \mathrm{cfs}$
RO \# $2=700 \mathrm{cfs}$
$\mathrm{RO} \# 3=700 \mathrm{cfs}$ 


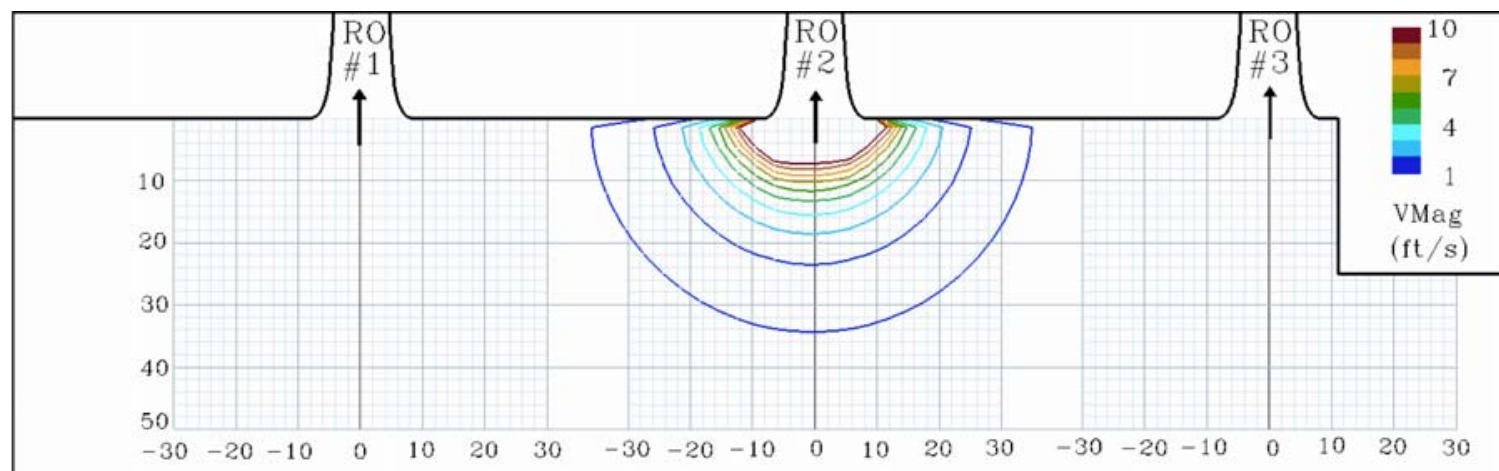

Plan View - Horizontal Slice at Elevation $1360 \mathrm{ft}$ - Axes units in ft.

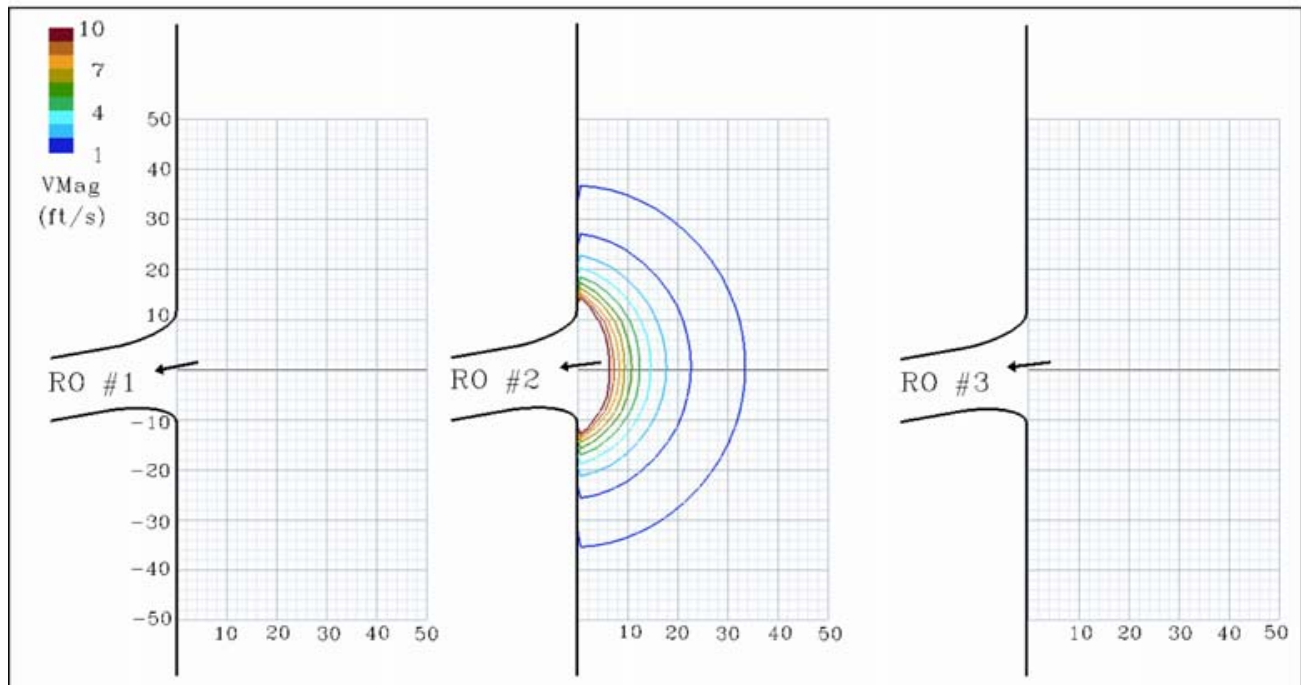

Side View - Vertical Slices along RO Centerlines - Axes units in ft.

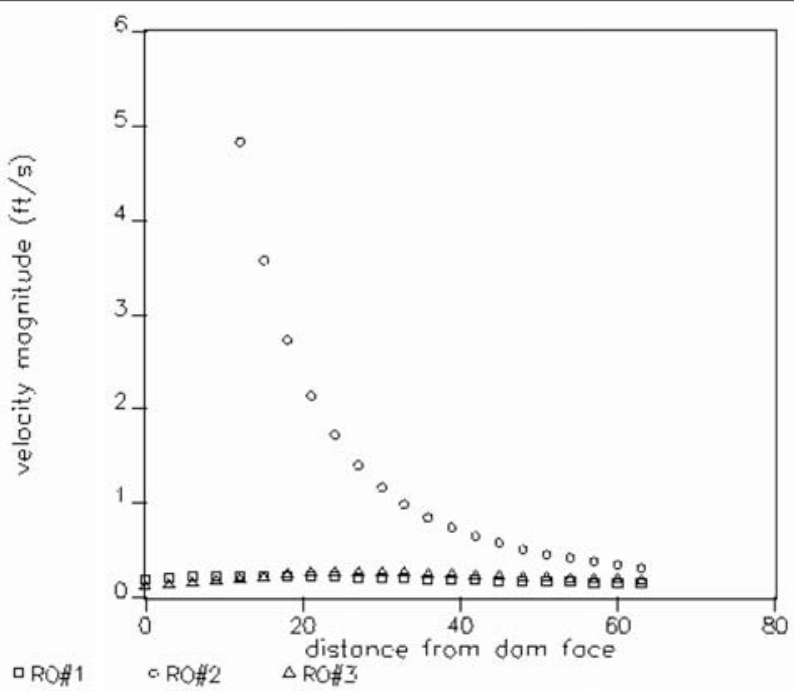

Run \#11

$\mathrm{WSE}=1500 \mathrm{ft}$

RO \# $1=0 \mathrm{cfs}$

$\mathrm{RO} \# 2=6700 \mathrm{cfs}$

RO \# $3=0 \mathrm{cfs}$ 




Plan View - Horizontal Slice at Elevation $1360 \mathrm{ft}$ - Axes units in ft.

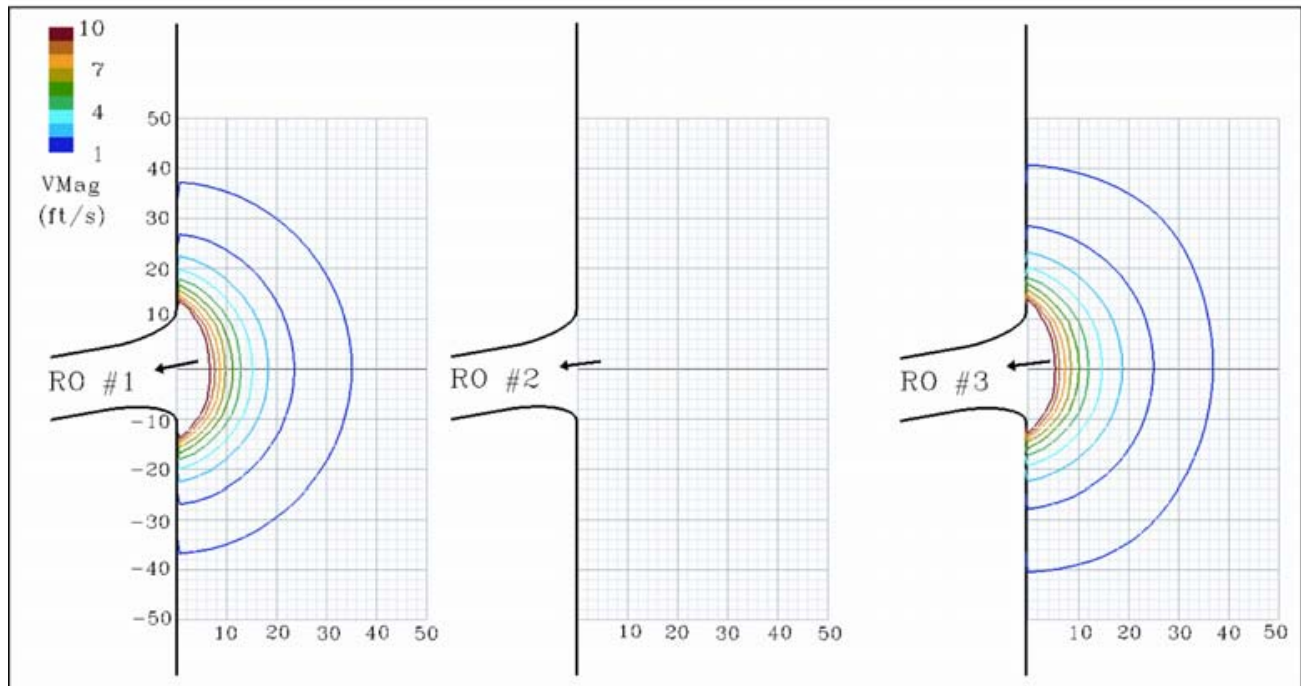

Side View - Vertical Slices along RO Centerlines - Axes units in ft.

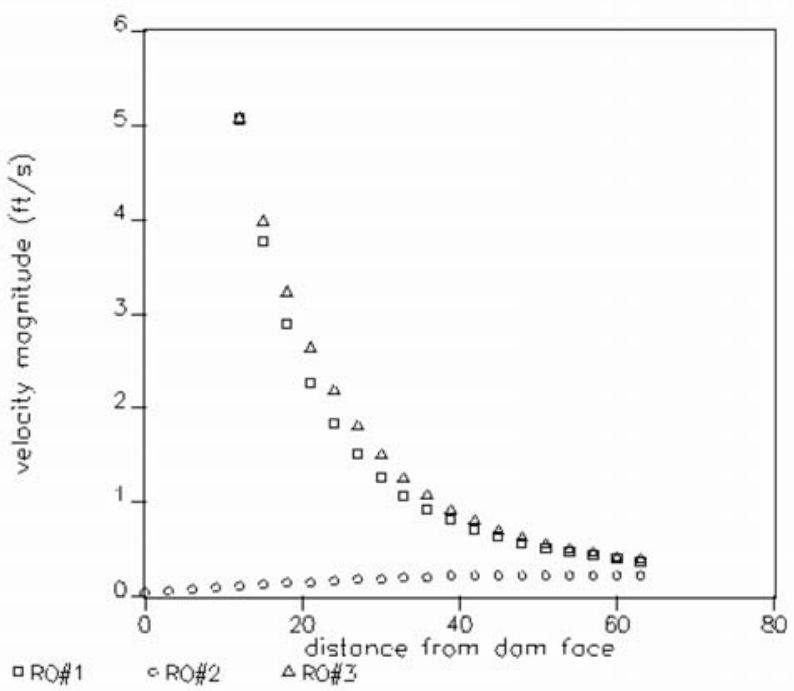
Run \#12
$\mathrm{WSE}=1500 \mathrm{ft}$
RO \# $1=6700 \mathrm{cfs}$
$\mathrm{RO} \# 2=0 \mathrm{cfs}$
RO \# $3=6700 \mathrm{cfs}$ 


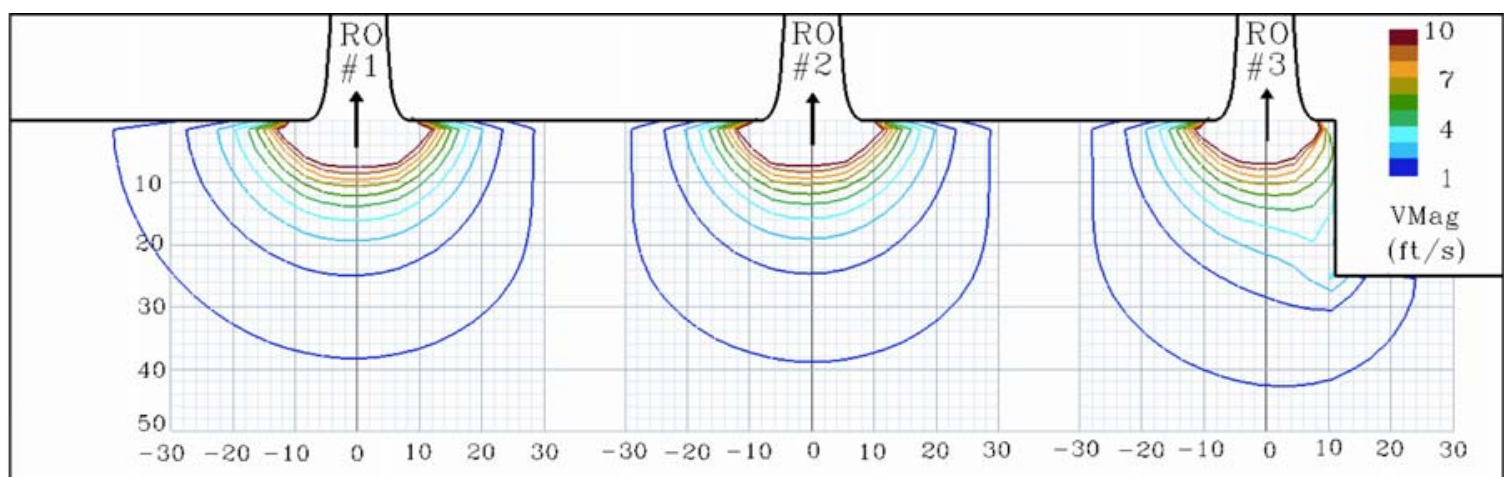

Plan View - Horizontal Slice at Elevation $1360 \mathrm{ft}$ - Axes units in ft.

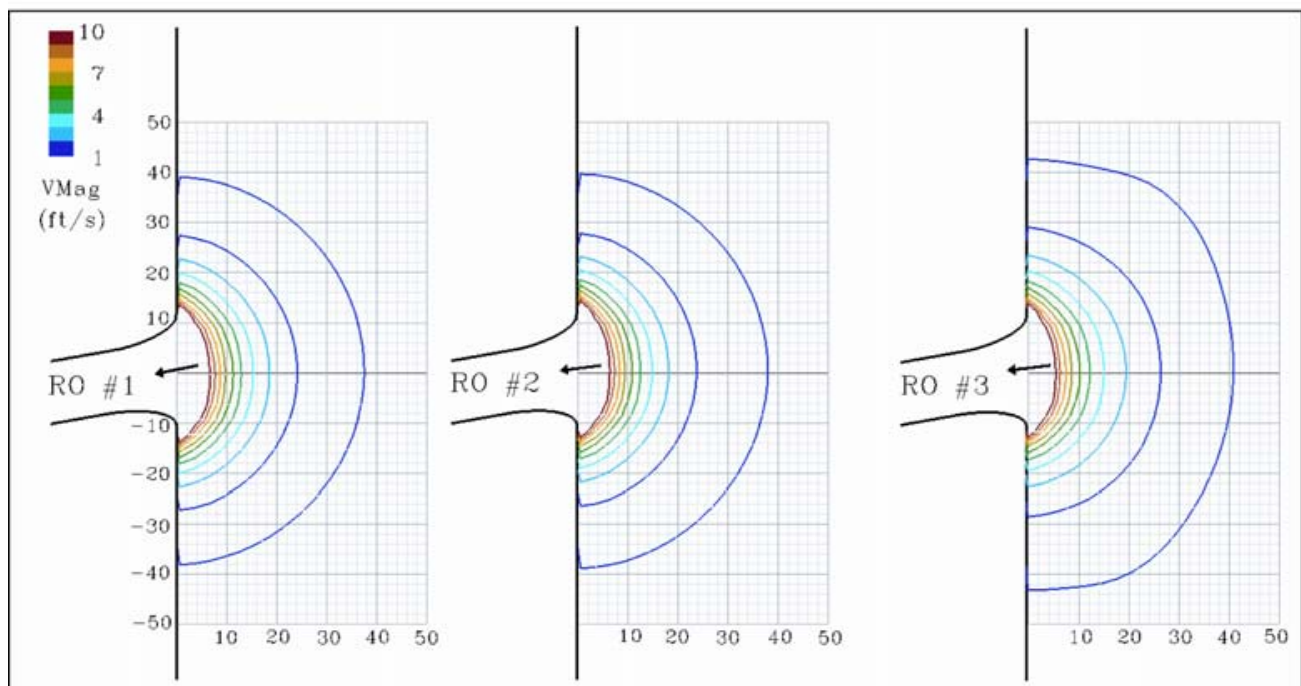

Side View - Vertical Slices along RO Centerlines - Axes units in ft.

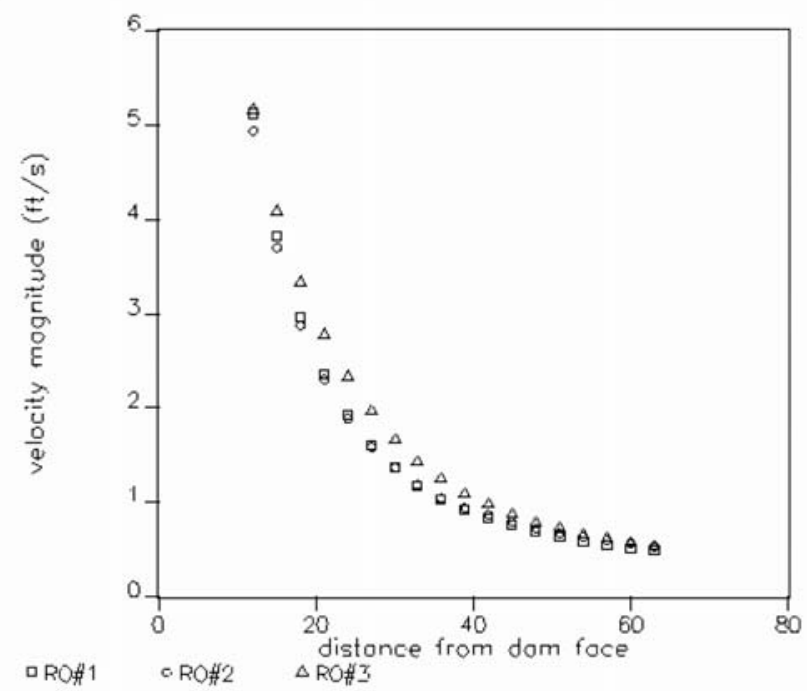

Run \#13

$\mathrm{WSE}=1500 \mathrm{ft}$

RO \# $1=6700 \mathrm{cfs}$

$\mathrm{RO} \# 2=6700 \mathrm{cfs}$

RO \# $3=6700 \mathrm{cfs}$ 




Plan View - Horizontal Slice at Elevation $1360 \mathrm{ft}$ - Axes units in ft.

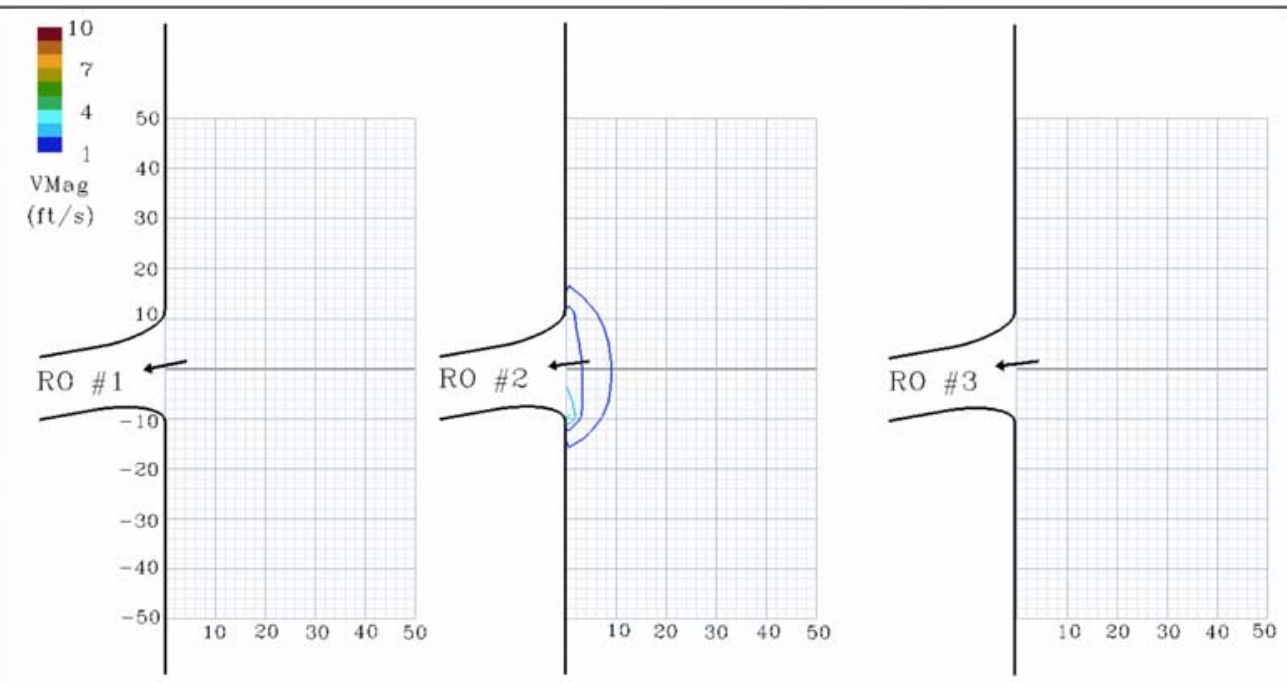

Side View - Vertical Slices along RO Centerlines - Axes units in ft.

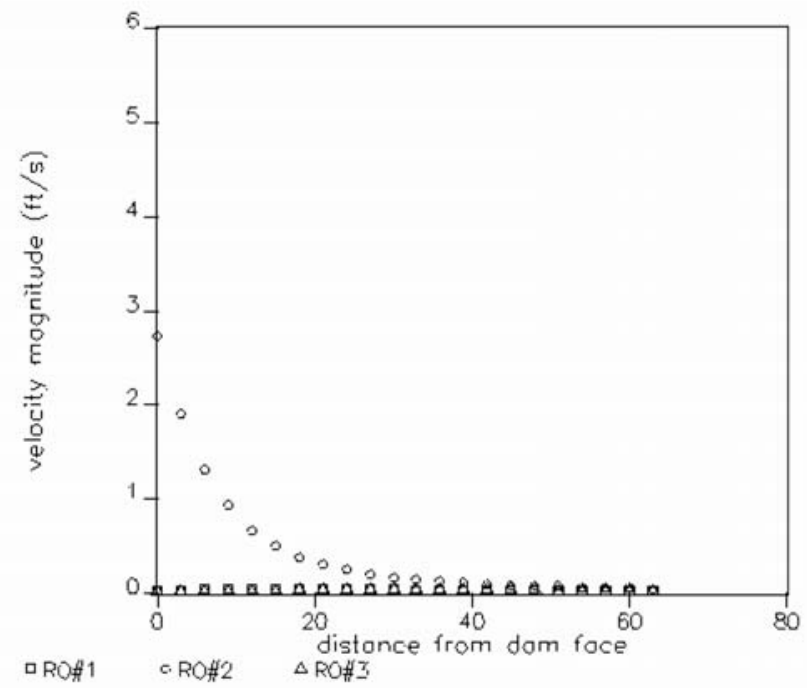

Run \#14

$\mathrm{WSE}=1560 \mathrm{ft}$

RO \# $1=0 \mathrm{cfs}$

$\mathrm{RO} \# 2=850 \mathrm{cfs}$

RO \# $3=0 \mathrm{cfs}$ 


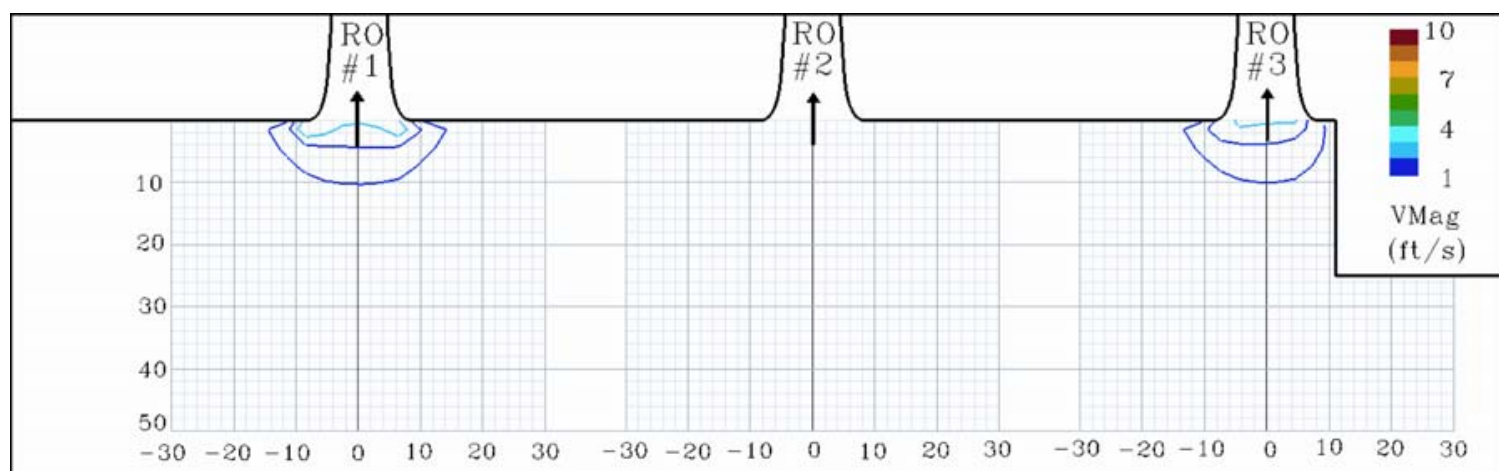

Plan View - Horizontal Slice at Elevation $1360 \mathrm{ft}$ - Axes units in ft.

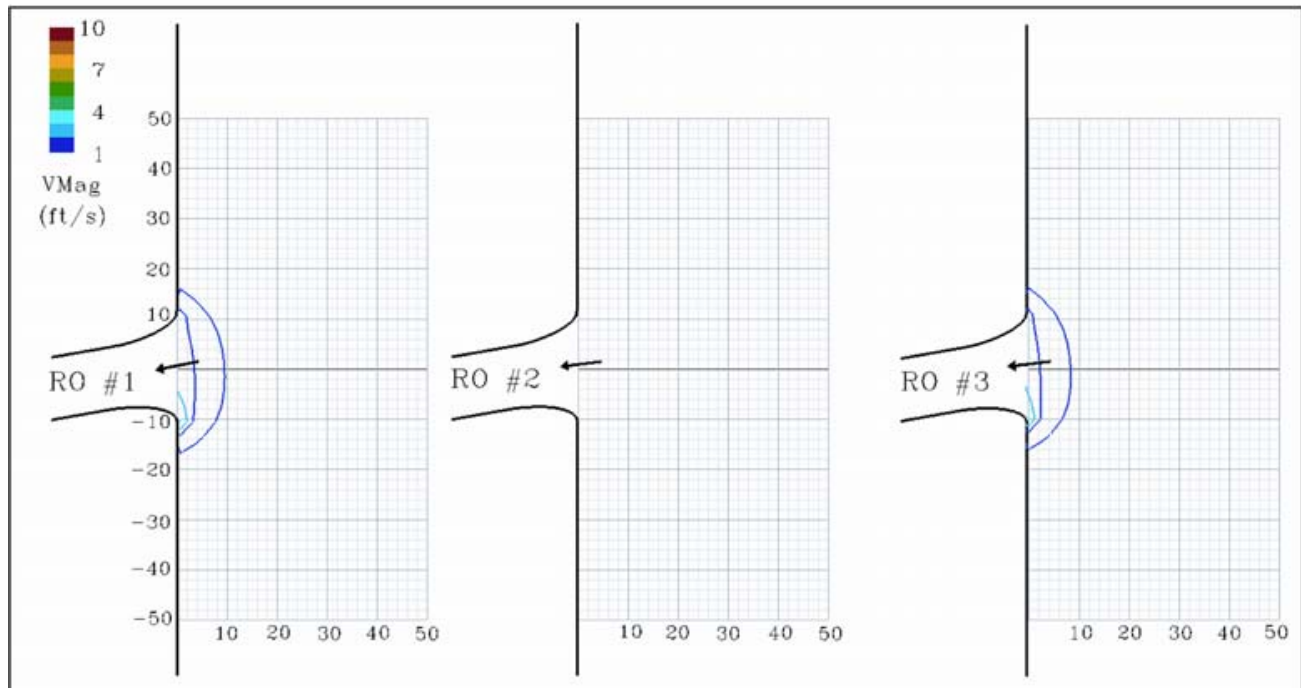

Side View - Vertical Slices along RO Centerlines - Axes units in ft.

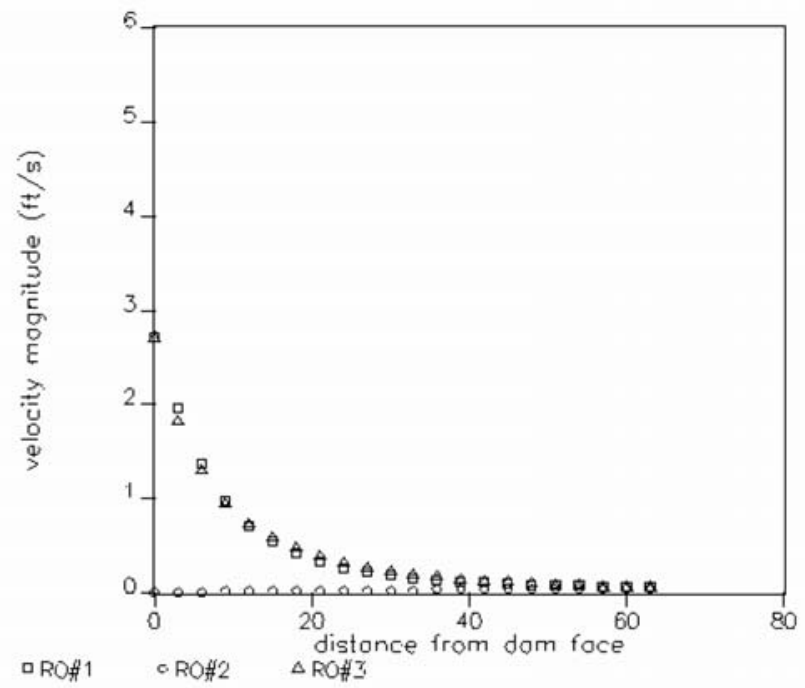

Run \#15

$\mathrm{WSE}=1560 \mathrm{ft}$

RO \# $1=850 \mathrm{cfs}$

RO \# $2=0$ cfs

RO \# $3=850 \mathrm{cfs}$ 




Plan View - Horizontal Slice at Elevation $1360 \mathrm{ft}$ - Axes units in ft.



Side View - Vertical Slices along RO Centerlines - Axes units in ft.

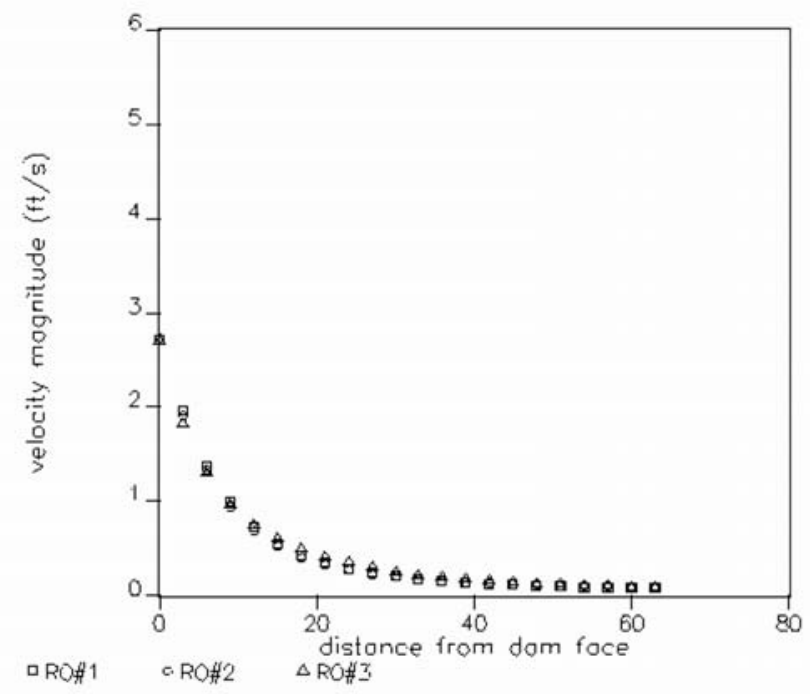

Run \#16

$\mathrm{WSE}=1560 \mathrm{ft}$

RO \# $1=850 \mathrm{cfs}$

$\mathrm{RO} \# 2=850 \mathrm{cfs}$

RO \# $3=850 \mathrm{cfs}$ 


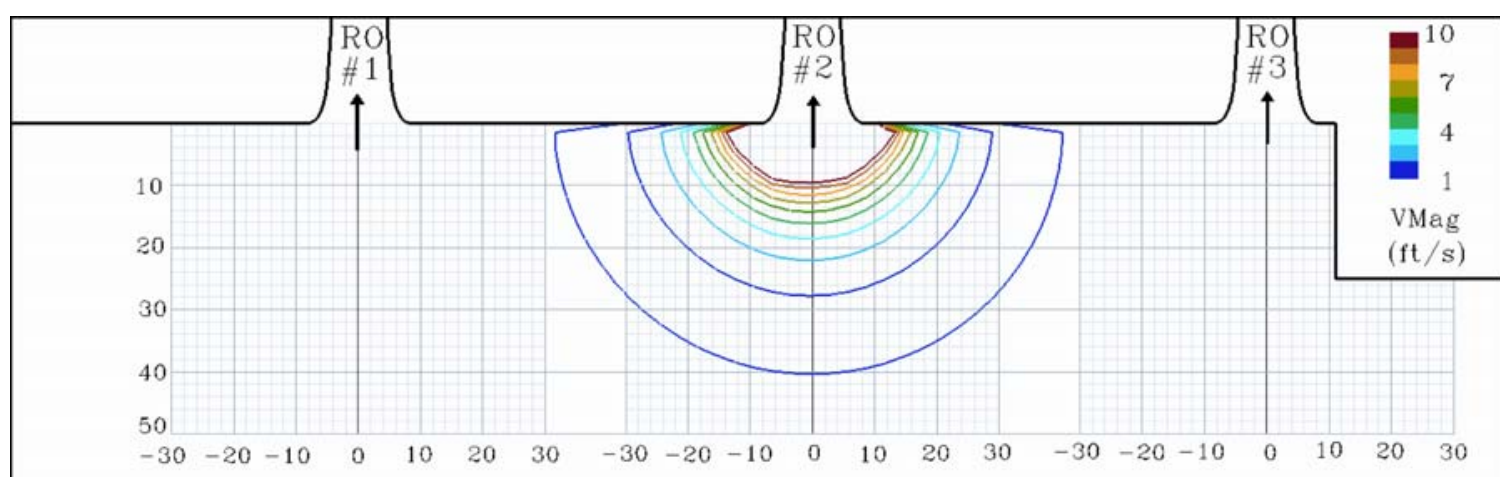

Plan View - Horizontal Slice at Elevation $1360 \mathrm{ft}$ - Axes units in ft.

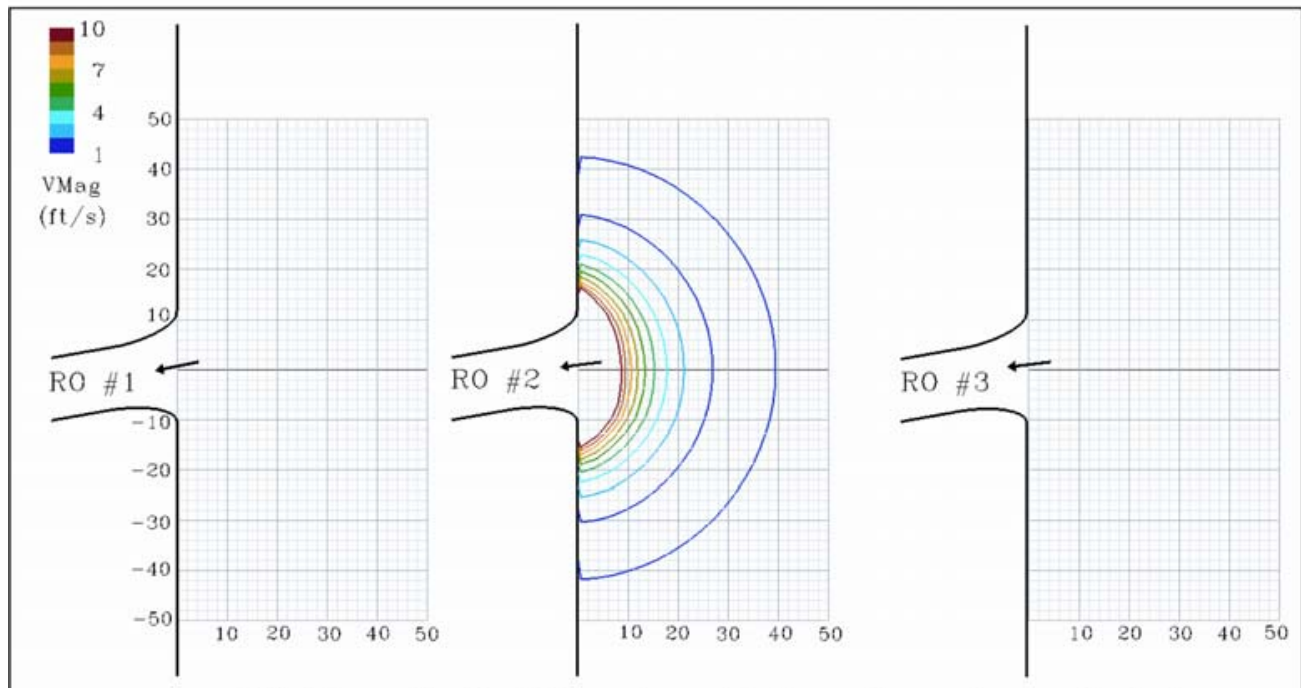

Side View - Vertical Slices along RO Centerlines - Axes units in ft.

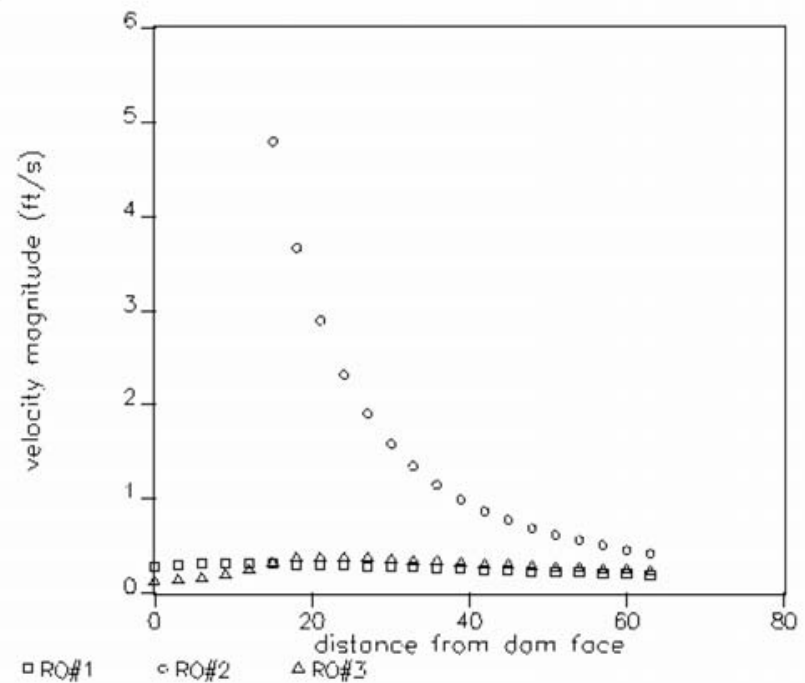
Run \#17
$\mathrm{WSE}=1560 \mathrm{ft}$
$\mathrm{RO} \# 1=0 \mathrm{cfs}$
$\mathrm{RO} \# 2=8100 \mathrm{cfs}$
$\mathrm{RO} \# 3=0 \mathrm{cfs}$ 


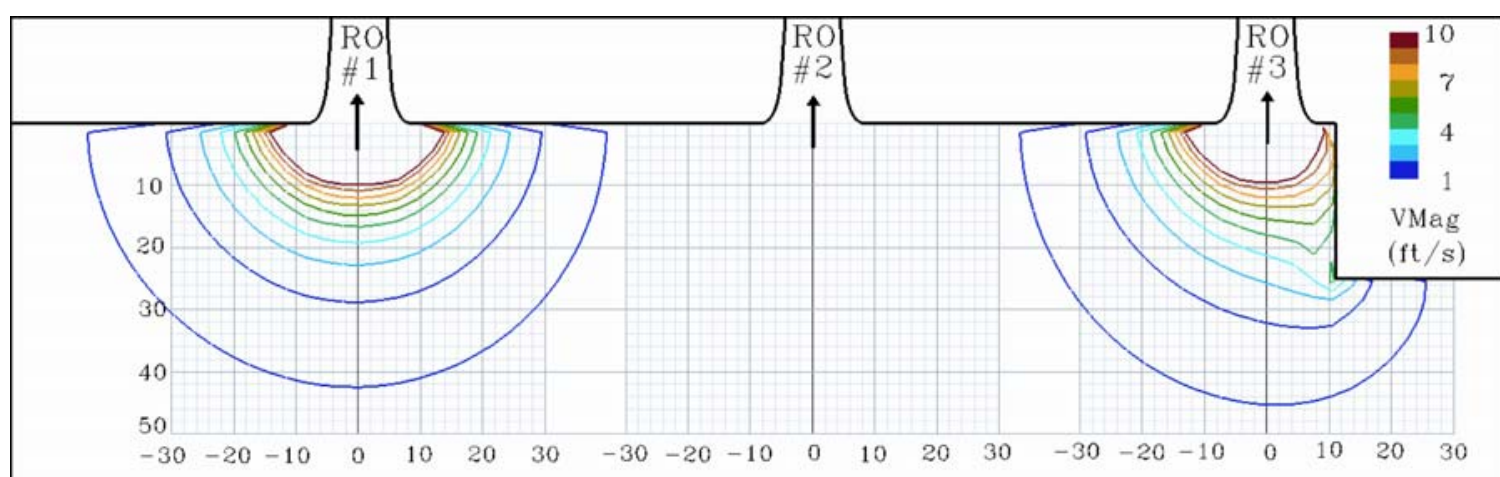

Plan View - Horizontal Slice at Elevation $1360 \mathrm{ft}$ - Axes units in ft.

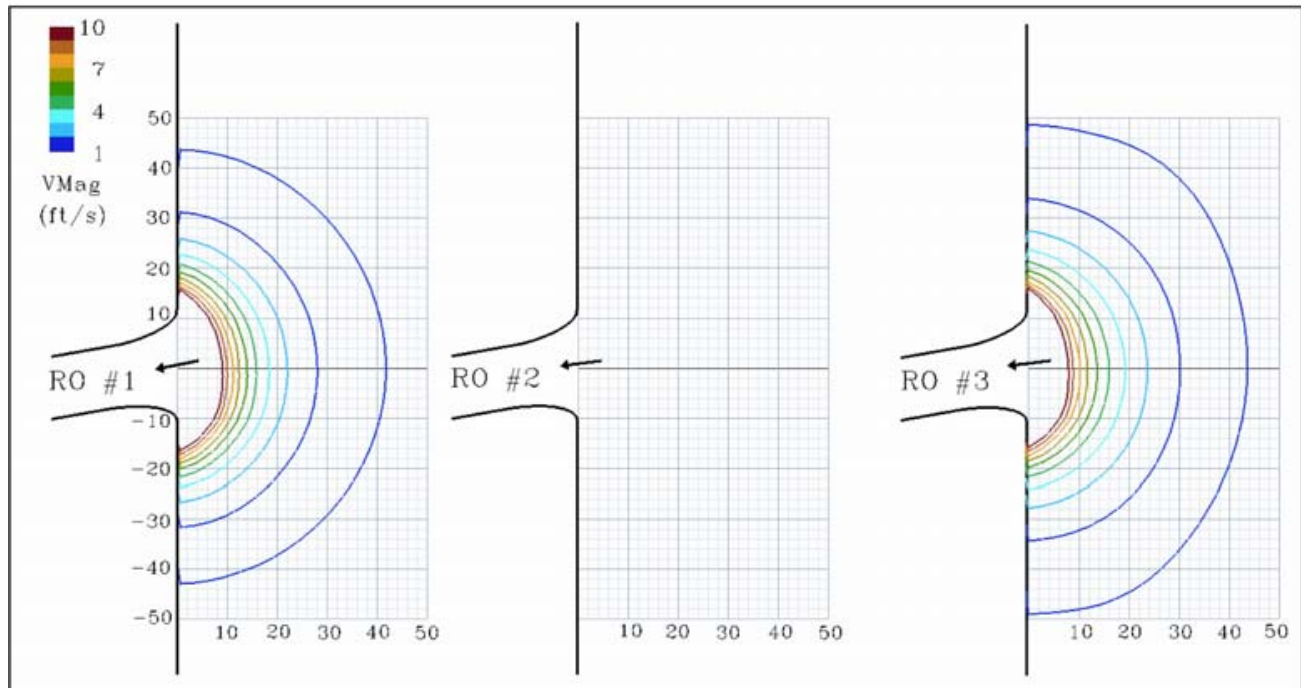

Side View - Vertical Slices along RO Centerlines - Axes units in ft.

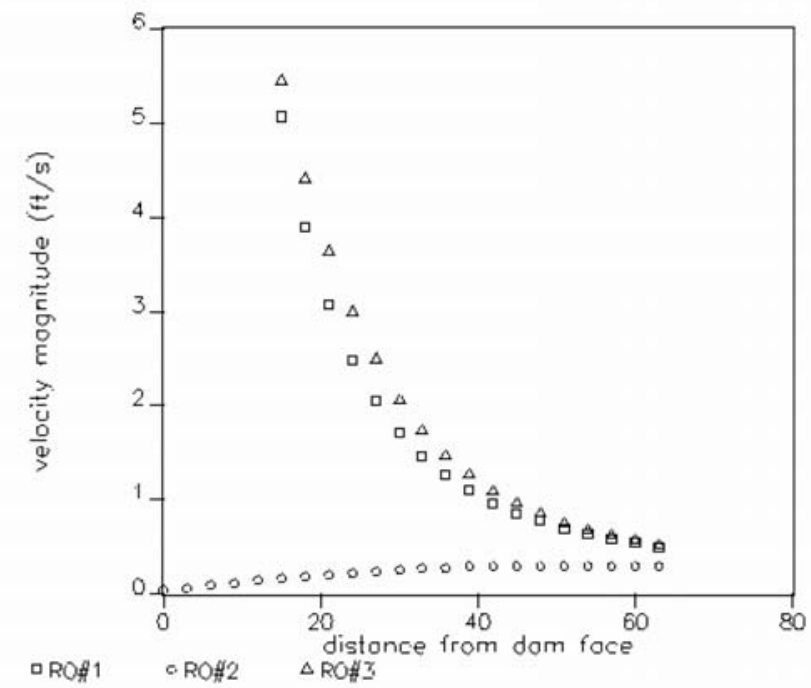

Run \#18

$\mathrm{WSE}=1560 \mathrm{ft}$

RO \# $1=8100 \mathrm{cfs}$

RO \# $2=0 \mathrm{cfs}$

RO \# $3=8100$ cfs 


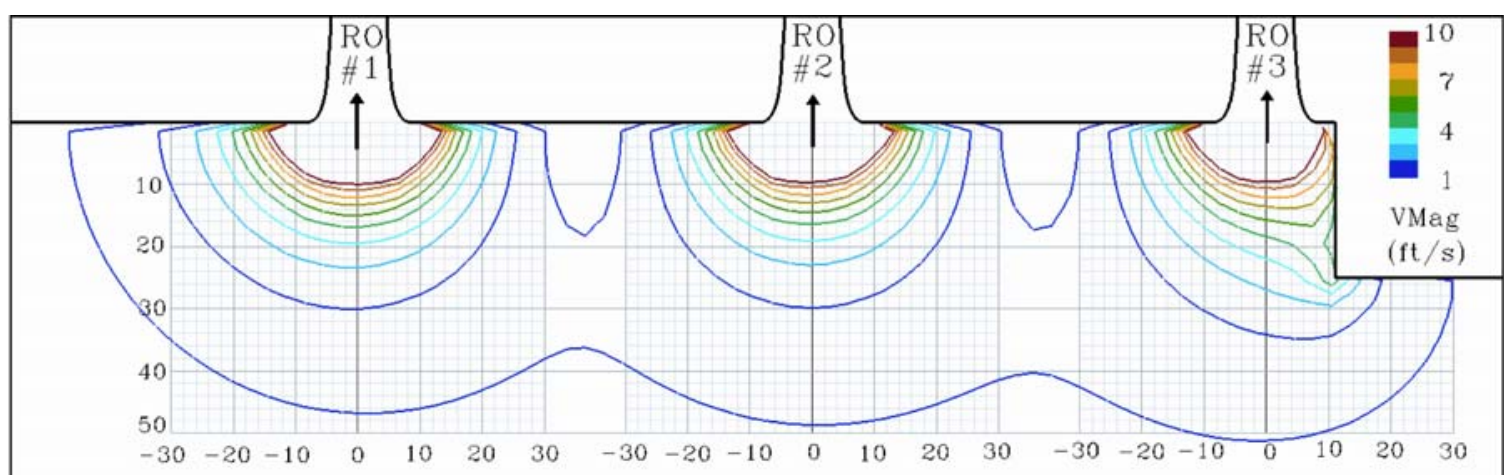

Plan View - Horizontal Slice at Elevation $1360 \mathrm{ft}$ - Axes units in ft.

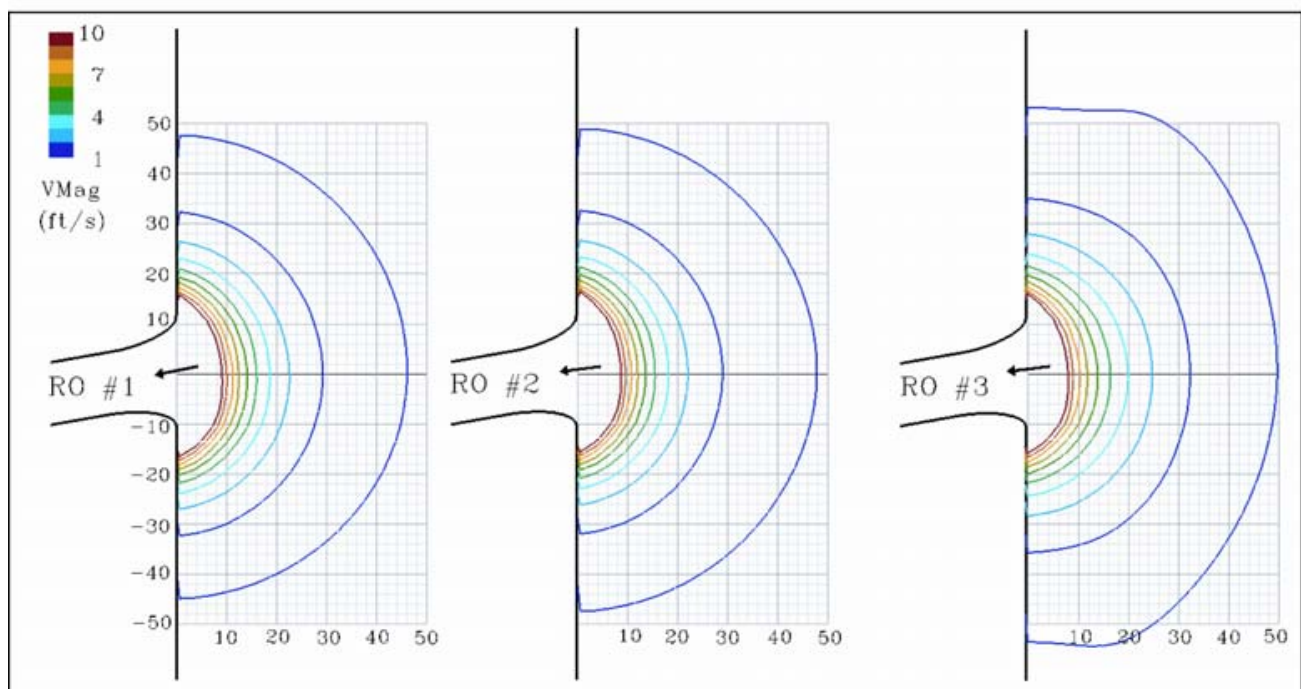

Side View - Vertical Slices along RO Centerlines - Axes units in ft.

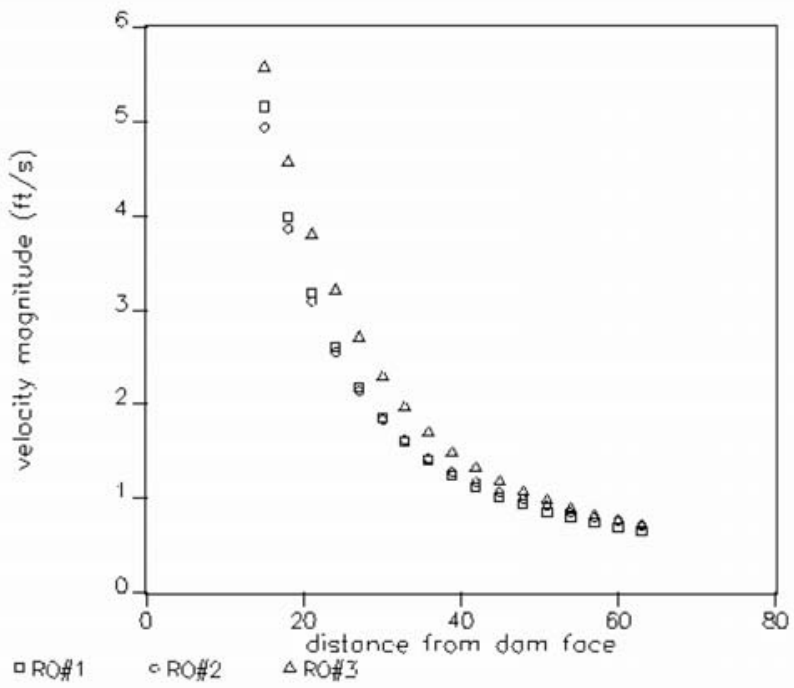
Run \#19
$\mathrm{WSE}=1560 \mathrm{ft}$
RO \# $1=8100 \mathrm{cfs}$
RO \# $2=8100 \mathrm{cfs}$
$\mathrm{RO} \# 3=8100 \mathrm{cfs}$ 


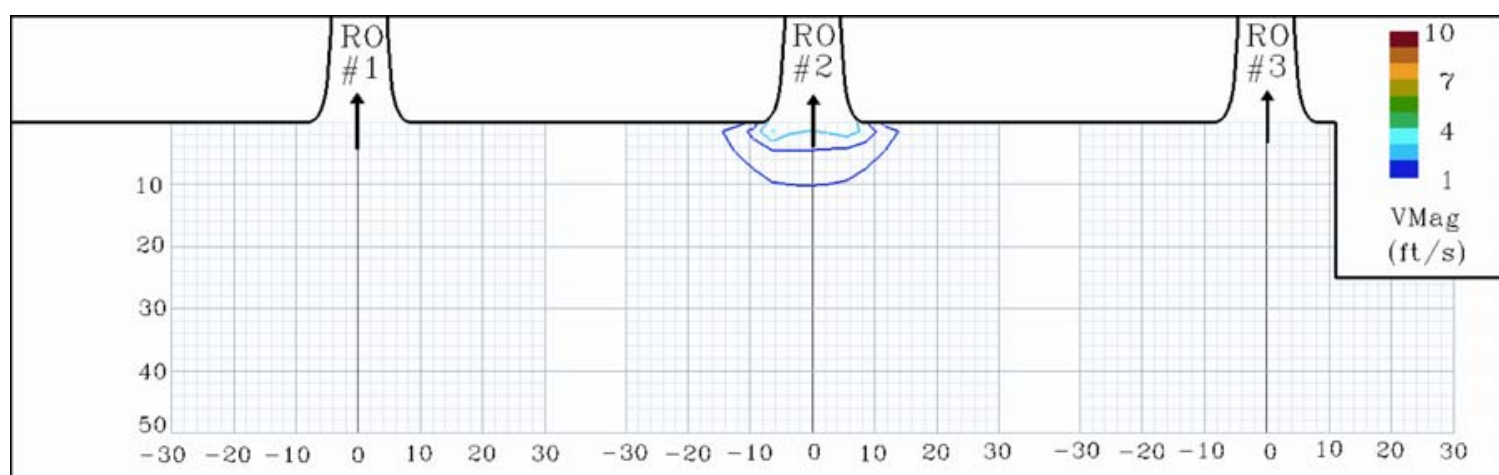

Plan View - Horizontal Slice at Elevation $1360 \mathrm{ft}$ - Axes units in ft.

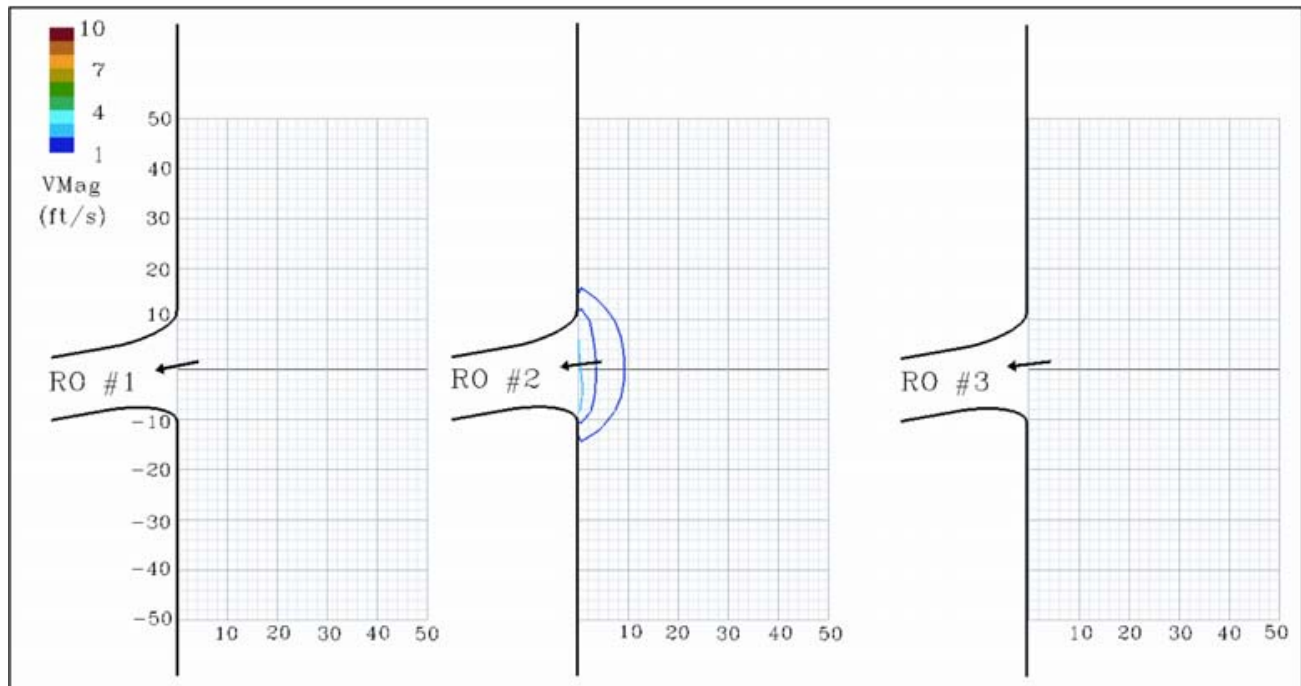

Side View - Vertical Slices along RO Centerlines - Axes units in ft.



Run \#20

$\mathrm{WSE}=1600 \mathrm{ft}$

RO \# $1=0 \mathrm{cfs}$

RO \# $2=950 \mathrm{cfs}$

$\mathrm{RO} \# 3=0 \mathrm{cfs}$ 




Plan View - Horizontal Slice at Elevation $1360 \mathrm{ft}$ - Axes units in ft.
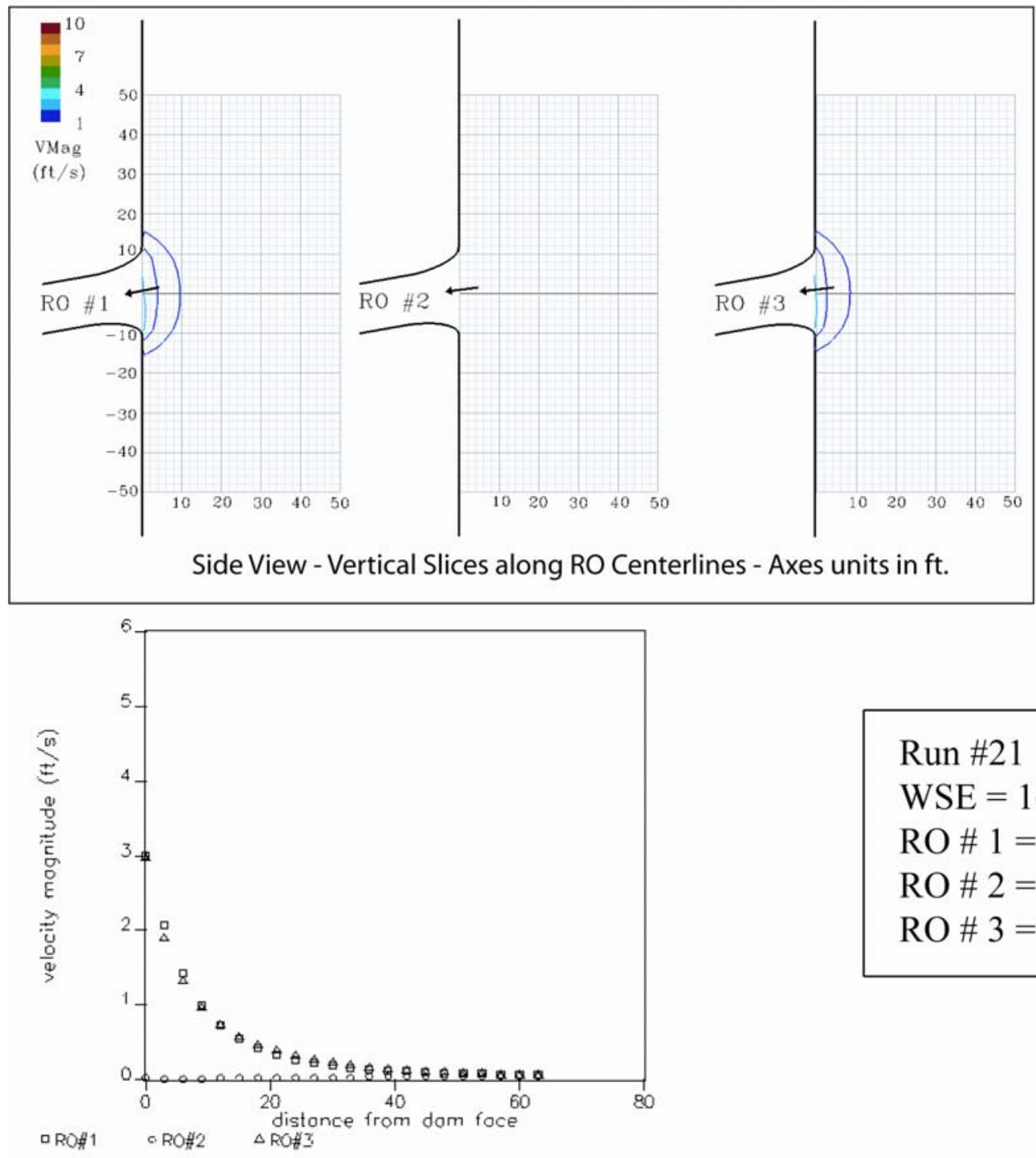

Run \#21

$\mathrm{WSE}=1600 \mathrm{ft}$

RO \# $1=950 \mathrm{cfs}$

RO \# $2=0 \mathrm{cfs}$

RO \# $3=950 \mathrm{cfs}$ 


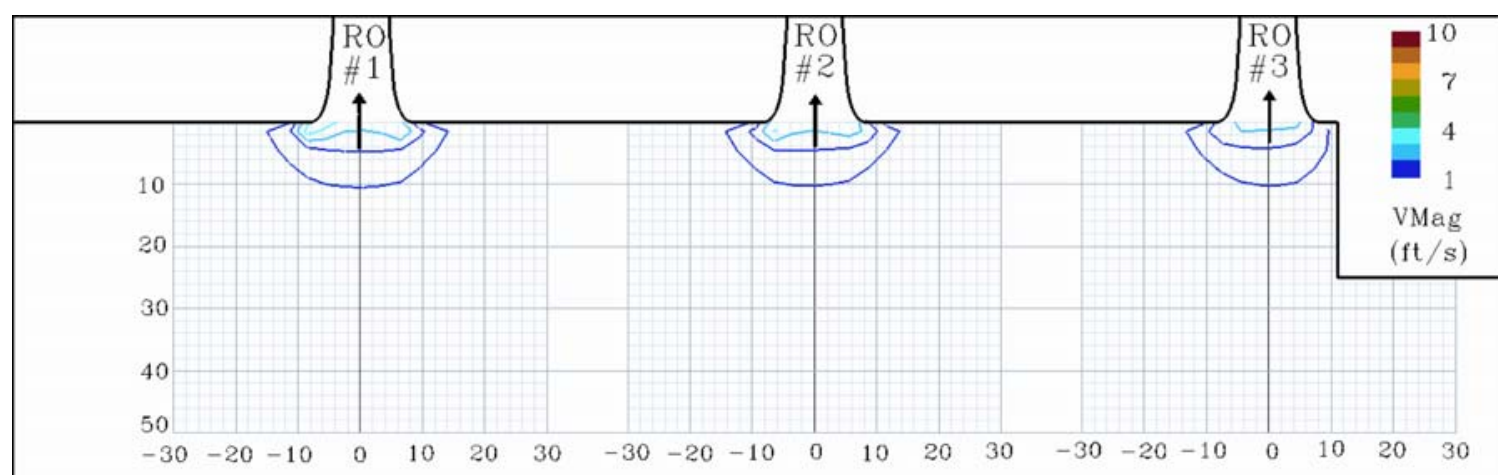

Plan View - Horizontal Slice at Elevation $1360 \mathrm{ft}$ - Axes units in ft.



Side View - Vertical Slices along RO Centerlines - Axes units in ft.

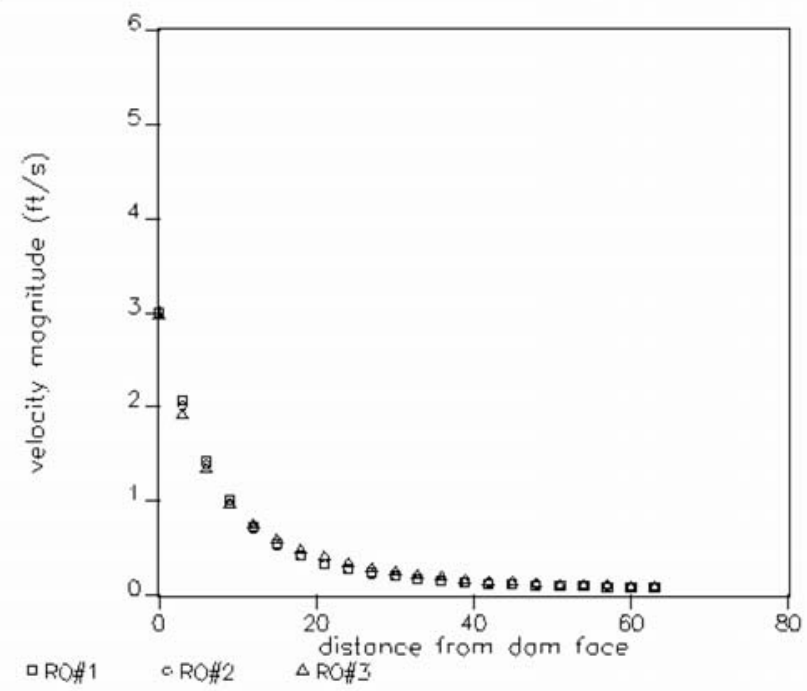
Run \#22
$\mathrm{WSE}=1600 \mathrm{ft}$
$\mathrm{RO} \# 1=950 \mathrm{cfs}$
RO \# $2=950 \mathrm{cfs}$
RO \# $3=950 \mathrm{cfs}$ 


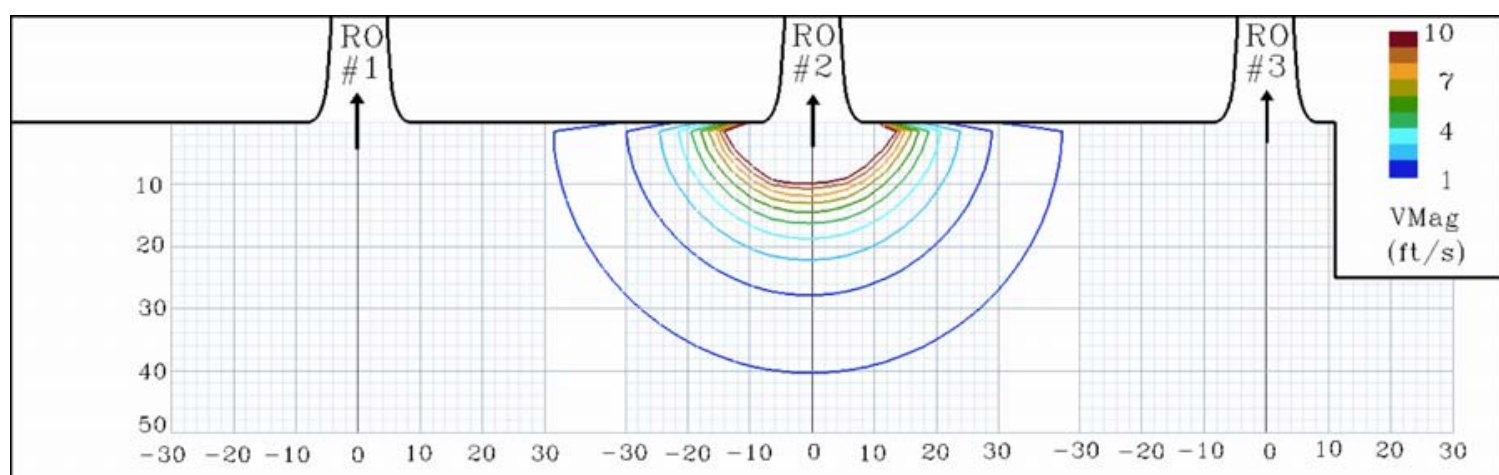

Plan View - Horizontal Slice at Elevation $1360 \mathrm{ft}$ - Axes units in ft.

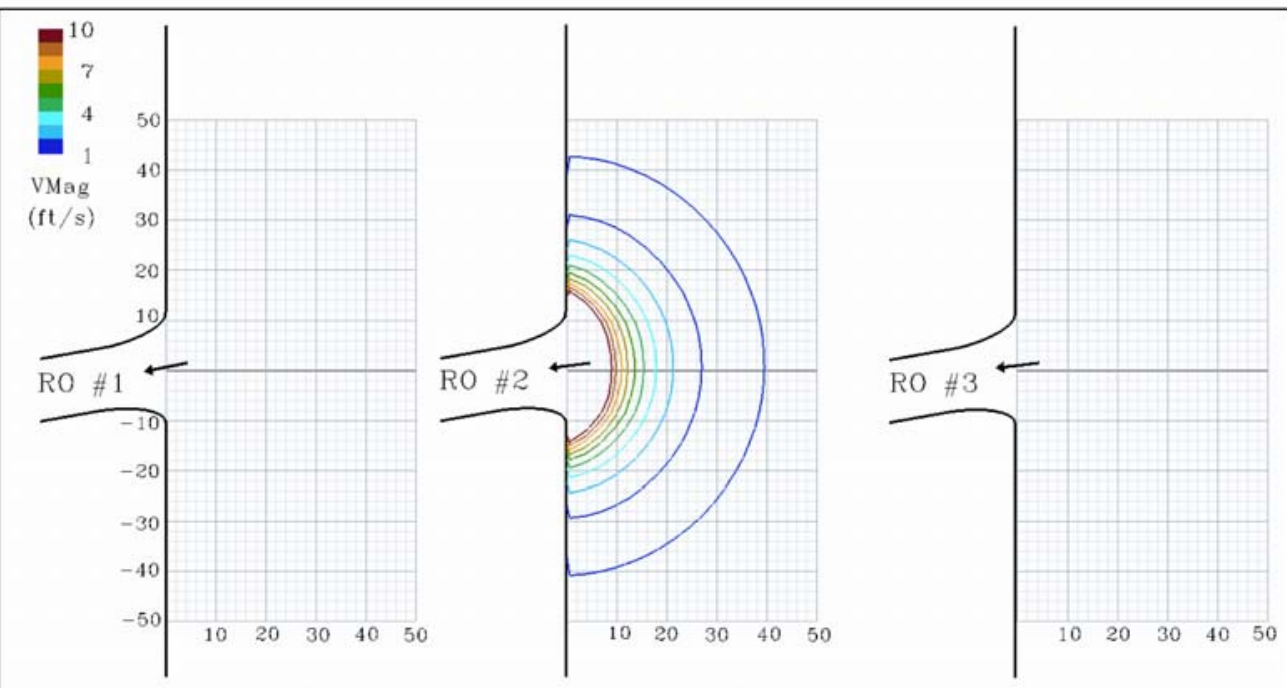

Side View - Vertical Slices along RO Centerlines - Axes units in ft.

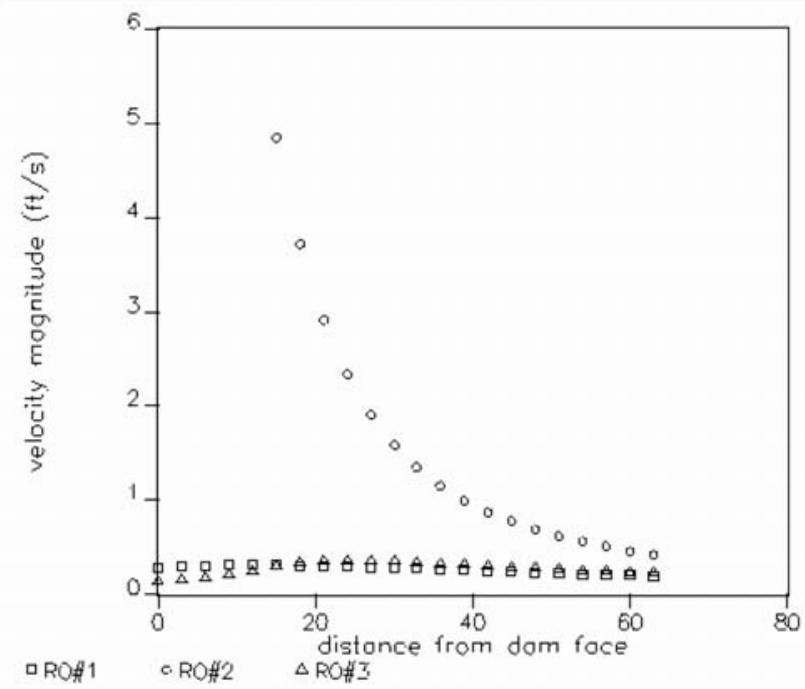
Run \#23
$\mathrm{WSE}=1600 \mathrm{ft}$
$\mathrm{RO} \# 1=0 \mathrm{cfs}$
RO \# $2=9100 \mathrm{cfs}$
$\mathrm{RO} \# 3=0 \mathrm{cfs}$ 




Plan View - Horizontal Slice at Elevation $1360 \mathrm{ft}$ - Axes units in ft.



Side View - Vertical Slices along RO Centerlines - Axes units in ft.



Run \#24

$\mathrm{WSE}=1600 \mathrm{ft}$

RO \# $1=9100 \mathrm{cfs}$

RO \# $2=0 \mathrm{cfs}$

RO \# $3=9100 \mathrm{cfs}$ 